\title{
Selective preservation of organic matter in marine environments; processes and impact on the sedimentary record
}

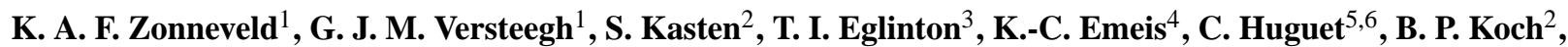 \\ G. J. de Lange ${ }^{7}$, J. W. de Leeuw ${ }^{6,7,8}$, J. J. Middelburg ${ }^{7,9}$, G. Mollenhauer ${ }^{2}$, F. G. Prahl ${ }^{10}$, J. Rethemeyer ${ }^{2}$, and \\ S. G. Wakeham ${ }^{11}$ \\ ${ }^{1}$ Fachbereich 5 - Geowissenschaften, Postfach 330440, 27412 Bremen, Germany \\ ${ }^{2}$ Alfred Wegener Institute for Polar and Marine Research, Am Handelshafen 12, 27570 Bremerhaven, Germany \\ ${ }^{3}$ Woods Hole Oceanographic Institution, Fye 111, MS\#4, Woods Hole, Ma. 02543, USA \\ ${ }^{4}$ Zentrum für Meeres- und Klimaforschung, Universität Hamburg, Bundesstraße 55, 20146 Hamburg, Germany \\ ${ }^{5}$ University of Washington, School of Oceanography, P.O. Box 355351, Seattle, WA 98195, USA \\ ${ }^{6}$ Royal Netherlands Institute for Sea Research, P.O. Box 59, 1790AB, Den Burg, The Netherlands \\ ${ }^{7}$ Geochemistry, Faculty of Geosciences, Utrecht University P.O. Box 80.021, 3508 TA Utrecht, The Netherlands \\ ${ }^{8}$ Institute of Environmental Biology, Faculty of Science, Utrecht University, The Netherlands \\ ${ }^{9}$ Netherlands Institute of Ecology, Centre for Estuarine and Marine Ecology, P.O. Box 140, 4400 AC Yerseke, \\ The Netherlands \\ ${ }^{10}$ College of Oceanic and Atmospheric Sciences, COAS Administration Building 104, Oregon State University, \\ Corvallis, OR 97331-5503, USA \\ ${ }^{11}$ Skidaway Institute of Oceanography, 10 Ocean Science Circle, Savannah, GA 31411, USA
}

Received: 3 June 2009 - Published in Biogeosciences Discuss.: 1 July 2009

Revised: 7 January 2010 - Accepted: 21 January 2010 - Published: 5 February 2010

\begin{abstract}
The present paper is the result of a workshop sponsored by the DFG Research Center/Cluster of Excellence MARUM “The Ocean in the Earth System", the International Graduate College EUROPROX, and the Alfred Wegener Institute for Polar and Marine Research. The workshop brought together specialists on organic matter degradation and on proxy-based environmental reconstruction. The paper deals with the main theme of the workshop, understanding the impact of selective degradation/preservation of organic matter $(\mathrm{OM})$ in marine sediments on the interpretation of the fossil record. Special attention is paid to (A) the influence of the molecular composition of OM in relation to the biological and physical depositional environment, including new methods for determining complex organic biomolecules, (B) the impact of selective OM preservation on the interpretation of proxies for marine palaeoceanographic and palaeoclimatic reconstruction, and (C) past marine productivity and selective preservation in sediments.

It appears that most of the factors influencing OM preservation have been identified, but many of the mechanisms by which they operate are partly, or even fragmentarily, under-
\end{abstract}

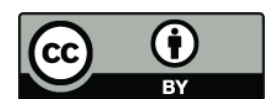

Correspondence to: G. J. M. Versteegh (versteegh@uni-bremen.de) stood. Some factors have not even been taken carefully into consideration. This incomplete understanding of OM breakdown hampers proper assessment of the present and past carbon cycle as well as the interpretation of OM based proxies and proxies affected by OM breakdown.

To arrive at better proxy-based reconstructions "deformation functions" are needed, taking into account the transport and diagenesis-related molecular and atomic modifications following proxy formation.

Some emerging proxies for OM degradation may shed light on such deformation functions. The use of palynomorph concentrations and selective changes in assemblage composition as models for production and preservation of OM may correct for bias due to selective degradation. Such quantitative assessment of OM degradation may lead to more accurate reconstruction of past productivity and bottom water oxygenation.

Given the cost and effort associated with programs to recover sediment cores for paleoclimatological studies, as well as with generating proxy records, it would seem wise to develop a detailed sedimentological and diagenetic context for interpretation of these records. With respect to the latter, parallel acquisition of data that inform on the fidelity of the proxy signatures and reveal potential diagenetic biases would be of clear value.

Published by Copernicus Publications on behalf of the European Geosciences Union. 


\section{Introduction}

Sedimentary organic matter $(\mathrm{OM})$ is the major reservoir of organic carbon in the global carbon cycle. In the marine environment it is composed of material derived from the various plankton species that comprise the ecology of primary producers and consumers in overlying surface waters. It is also composed of allochthonous materials introduced erosionally from the land by fluvial and eolian transport processes, products from chemical transformations and condensation reactions, as well as re-synthesis products derived from heterotrophic microbial activity that drives OM decomposition during diagenesis. Only a fraction of the organic material that is produced within the upper water column reaches the sea floor, where it is further degraded by aerobic and anaerobic remineralisation processes and it has been estimated that roughly only about $1 \%$ of the originally produced OM might be transferred to the deep biosphere (e.g. Suess, 1980; Hedges and Keil, 1995; Middelburg and Meysman, 2007). During the last few decades it has become clear that preservation is highly selective, and that the amount and composition of OM preserved in marine sediments varies greatly among regions and depositional environments.

Marine sedimentary OM forms the basis of many proxies used for reconstructing climate and environment. Since these proxies often provide the foundation for these reconstructions, it is essential to have detailed information about the character and influence of selective preservation on them.

The chemical, physical and biological effects on OM degradation as well as the effect of selective degradation on proxy reliability are key topics within a large number of scientific research disciplines. However, until now "synergetic" discussion has been scarce. This is well illustrated by the fact that information about these subjects is scattered throughout the literature in journals of the individual disciplines. Combining this information was the subject of a workshop of the DFG Research Center/Cluster of Excellence MARUM "The Ocean in the Earth System", the International Graduate College EUROPROX, both based at the University of Bremen, Germany and the Alfred Wegener Institute for Polar and Marine Research in Bremerhaven, Germany, from 27 to 30 September 2007. During this workshop specialists from the fields of organic and inorganic geochemistry, biogeochemistry, microbiology, paleoceanography and micropaleontology integrated their expertise on selective degradation/preservation of OM in marine sediments. Within this paper we present an overview of

1. the present state of knowledge of the effect of the molecular composition of OM and the biological and physical depositional environment on OM preservation,

2. the potential impact of selective OM preservation on the interpretation of several OM-based proxies and methods that are presently used in marine paleoceanographic and palaeoclimatic research with the main focus on organicgeochemical and chemical proxies, and

3. identification and quantification of past marine production and selective preservation of $\mathrm{OM}$ in fossil sediments.

\subsection{Factors that influence OM preservation}

Several factors have been put forward as the primary controls on OM burial and preservation in sediments. First of all, the amount of OM produced in and supplied to the upper ocean waters, together with the amount and type of mineral ballast, determines the rain rate and the composition of $\mathrm{OM}$ delivered to the seafloor. This OM input is either generated by primary production in the photic zone or through transport of terrestrial OM to the marine realm. Whereas degradation of the first source of OM occurs entirely within the marine environment, terrestrial OM can already be altered quite significantly before entering the marine system. OM from both sources may contain compounds that are intrinsically labile or refractory purely on the basis of their molecular structures (e.g. elemental composition, presence of functional groups) and the physical form in which they exist in nature (Sollins et al., 1996; Hedges and Oades, 1997). These aspects will be discussed in Sect. 2.1. The importance of the refractory humic fraction in marine organic matter is discussed in Sect. 2.2 and special attention is paid to Fouriertransform ion cyclotron resonance mass spectrometry as a new method to shed light on the composition of the unresolved complex mixtures that comprise environmental samples. For terrestrial OM, degradation processes in soils and during transport largely influence its molecular structure and determine its degradation potential when entering the marine environment. These processes are addressed in Sect. 2.3.

A second factor that strongly affects OM preservation is oxygen availability which determines the respiratory types of benthic organisms, with anaerobic consortia of microorganisms being slightly less efficient degraders of $\mathrm{OM}$ than aerobic micro-organisms and micro- and macrofauna (e.g. Simon et al., 1994; Bastviken et al., 2004). Redox oscillations may enhance degradation by promoting symbiosis of aerobes and anaerobes (Canfield, 1994; Aller, 2001; Aller and Blair, 2006). Apart from the effect on the microbial community, oxygen availability, notably in the mesopelagic or "twilight" zone and benthic boundary layer (and thus in surface sediments) largely determines the occurrence and community structure of metazoans. An overview on how this aspect might influence OM degradation and preservation is given in Sect. 2.4.

Physical factors of the depositional environment such as sediment texture and temperature, might have a direct influence on the exposure time to oxygen or other degrading agents such as enzymes. Newly-formed polymers during the degradation or aging process can isolate the OM from the 
degrading agent, and as such protect the OM from (further) degradation. Furthermore, the mineral surfaces of the sediments or the macromolecular organic matrices can protect OM from degradation (Knicker and Hatcher, 1997, 2001; Hedges and Keil, 1999; van Dongen, 2003; Versteegh et al., 2004; Arnarson and Keil, 2005; de Leeuw et al., 2006; Gupta et al., 2007). More information about these aspects is provided in Sect. 2.5.

\subsection{Influence of selective OM preservation on marine palaeoceanographic proxies}

Within the scope of the current concern of global (climatic) change there is an urgent need for accurate estimation of past oceanic conditions. The role of the oceans in the global carbon cycle is ever more apparent, and the international community is seeking answers to questions concerning the range of variation in marine production, ocean circulation, and carbon sequestration, and how these are linked to atmospheric $p \mathrm{CO}_{2}$ variations through Earth's history. Furthermore, the direct link between the upper ocean and the atmosphere means that detailed reconstruction of past conditions in the upper ocean is essential to understanding the causes and effects of past climate change. However, proper constraints on the processes that control carbon fluxes between the ocean and the atmosphere, and on upper ocean circulation, are still lacking. This is partly due to constraints and limitations of the proxy methods currently used. Within the last decades it became apparent that diagenetic processes related to $\mathrm{OM}$ degradation can strongly influence the initial signals of many proxies, thereby impeding the interpretation of the signals. As a result, researchers are increasingly seeking to characterize and quantify this influence. These aspects form the central theme of Sects. 3 and 4 of this manuscript. Within Sect. 3 the effect of selective OM degradation on several lipid-based proxies is evaluated. The first proxy discussed in Sect. 3.1 is radiocarbon to determine the age of sedimentary carbon younger than $\sim 50 \mathrm{ka}$. The establishment of an accurate detailed stratigraphic framework is an essential aspect of paleoceanographic and paleoclimatic research. Within the last several years the analytical techniques to determine radiocarbon ages of sediments and the transfer to calendar age have improved enormously. However, these detailed measurements document that individual sedimentary OM components can have radiocarbon ages that differ considerably, sometimes as much as several thousands of years. There are strong indications that selective OM degradation of different components forms a major cause for these discrepancies.

We continue the discussion with the consequences of selective preservation of lipids (Sect. 3.2) and especially the impact of selective degradation on two lipid-based proxies (Sect. 3.3 and 3.4) that are used to determine past sea surface temperatures (SSTs); i.e. the long-chain ketone based unsaturation index $\left(\mathrm{U}_{37}^{K^{\prime}}\right)$ and the $\mathrm{TEX}_{86}$ index, the latter one based on isoprenoidal glycerol dialkyl glycerol tetraethers
(GDGTs). Knowledge of SSTs is important for climate models as well as for elucidating the mechanisms of past climate change. Temperature reconstructions beyond the instrumental period strongly rely on well-dated high-resolution proxyrecords reconstructed using paleothermometers. Specifically, to reconstruct SST from marine sediment records, a large range of tools and analytical techniques have been developed. Nevertheless, the establishment of detailed upper ocean temperature reconstructions is still not trivial and the improvement of many traditionally-used proxies, as well as the establishment of new proxies, currently forms the theme of many research programs.

The same holds for the quantitative estimation of the past marine carbon flux through the water column, and the amount of carbon burial. Proxies that are presently used to estimate past upper ocean carbon production as well as the preservation and mineralization rates in bottom sediments are discussed in Sect. 4. We begin this chapter with an evaluation of barium as a tracer to reconstruct productivity and compare this proxy to the traditionally used proxy for productivity: the amount of total organic carbon in bottom sediments. We continue our discussion in Sect. 4.2 with the use of selective preservation of recognisable marine OM particles to separate the initial productivity signal from the post depositional aerobic degradational overprint. Although we focus on the use of palynomorphs for which much information is available on their production in the upper water column, this method has the potential to be used with other OM components as well.

\section{Selected factors affecting $O M$ preservation}

\subsection{OM composition}

The predominant fraction of sediment and soil OM is operationally defined as kerogen, high-molecular-weight OM not soluble in organic solvents or water. This kerogen by definition is preserved OM, i.e. the very small fraction of OM $(0.5-1 \%)$ that continuously escapes from the biochemical cycle into the geosphere.

Determining the origin and structure of kerogen on the molecular level is not an easy task because of its highmolecular weight and insolubility. However, significant progress has been made over the last decades through use of combined spectroscopic (e.g. ${ }^{13} \mathrm{C}$ solid state NMR, FT-IR), pyrolytic and specific chemical degradation methods and techniques (de Leeuw et al., 2006 and references cited herein; de Leeuw, 2007). It has become clear that under favourable depositional conditions several types of aliphatic (cutan, cutin, suberan, suberin) and aromatic (lignin, sporopollenin, dinosporin) cell-wall biopolymers biosynthesized to protect organisms, spores, pollen and cysts, are selectively preserved relative to polysaccharides, proteins and other biopolymers. 
Apart from this selective preservation of biopolymers, novel types of geopolymers can be generated upon early diagenesis depending on the depositional environment. In anoxic marine settings, functionalized lipids or even sugars can react with $\mathrm{H}_{2} \mathrm{~S}$ or polysulfides, resulting in the formation of polymeric substances cross-linked via (poly)sulfur bridges. Upon further diagenesis, these compounds can release the original lipid moieties by C-S cleavage and/or become stabilized geochemically e.g. by (benz)thiophene formation (e.g. Sinninghe Damsté and de Leeuw, 1990).

In a similar fashion, functional lipids can also polymerize under oxic conditions by oxygen cross-linking (e.g. Harvey et al., 1983; Versteegh et al., 2004). The latter phenomenon can be compared to the drying process of linseed oil, a process long known to occur during the drying of oil paint and varnish (Blom, 1936). It should be emphasized, however, that upon very long oxygen exposure times, as illustrated by the very low levels of OM in oxic deep-sea sediments and oxidized turbidites, essentially all sedimentary OM, including the presumed resistant biopolymers and the geopolymers described above, are ultimately mineralized.

\subsection{Resolving unresolved complex mixtures: molecular characteristics of natural OM determined by FT-ICR-MS}

The existence of persistent marine OM such as kerogen has important implications for biogeochemical cycles:

- it serves as a buffer in the global organic carbon cycle,

- it can support the preservation of other organic molecules or trace elements which are applied as proxies in the fossil record, and

- global environmental changes can alter the balance of preservation versus mineralization of organic matter with potentially major implications for carbon fluxes between reservoirs.

It may also hold as-of-yet untapped paleo-proxy information. For all of these reasons, there is a strong need to elucidate sources, preservation and degradation mechanisms of this material using molecular techniques.

The highly complex composition of kerogen and its diagenetic precursors is a major obstacle for the comprehensive characterization of organic carbon in oceanic dissolved colloidal and particulate pools. Until recently, no instrumental method could provide the analytical breadth and resolution to cover this complexity. Instead, molecular-level information was derived predominantly from specific and highly selective extraction and degradation methods which only provide a window into a small fraction of the total material. For this reason, the majority of the reworked organic matter in marine sediments and water has remained molecularly uncharacterized (Hedges et al., 2000). Whereas in the surface ocean most of the fresh organic matter is relatively well characterized (typically carbohydrates, proteins and lipids), after early diagenesis these "fresh" biomolecules usually contribute less than $10 \%$ to the total organic carbon. The remaining $90 \%$ persists on longer time scales (e.g. the turnover time of marine dissolved OM in the deep water column is $\sim 5000$ years (Williams and Druffel, 1987; Bauer et al., 1992), and its complexity hampers our ability to develop a molecular-level understanding of OM sources and bioavailability, OM min$\mathrm{eral} / \mathrm{metal}$ interactions, and to constrain other aspects of $\mathrm{OM}$ cycling.

The recent development of ultrahigh resolution Fourier Transform Ion Cyclotron Resonance Mass Spectrometry (FT-IR-MS; e.g. Marshall et al., 1998) has greatly expanded the "analytical window" available for unravelling the composition of hitherto "uncharacterizable" OM. The technique resolves thousands of individual molecular species based on precise mass determinations, and has been used to constrain molecular formulas (including $\mathrm{N}$ and $\mathrm{S}$ compounds) for components in highly complex mixtures such as oils (Schaub et al., 2005), terrestrial humic substances (Kujawinski et al., 2002; Stenson et al., 2003; Koch et al., 2007), aerosols (Reemtsma et al., 2006), and dissolved OM from the oceanic water column (Koch et al., 2005; Hertkorn et al., 2006; Sleighter and Hatcher, 2008) sediment porewaters (Schmidt et al., 2009) and organic extracts derived from soil (e.g. Kujawinski et al., 2002; Kramer et al., 2004; Hughey et al., 2008) and rock samples (Khanna et al., 2008). FTICR-MS enables molecular differences between organic matter sources and selective molecular preservation induced by processes such as microbial and photo-degradation to be examined (e.g. Kujawinski et al., 2004). Coupling this analytical technique with polarity-based chromatography facilitates separation of dissolved OM into well defined and less complex fractions enhancing information on selective preservation and the diagenetic state of OM (Koch et al., 2008).

Although the extent of compositional information derived from FT-ICR-MS is still limited due to the complexity of ions which are measured simultaneously, in a few cases unique molecular formulas can be assigned. For example, large, hydrogen-deficient molecules which were identified in natural organic matter in soils (Hockaday et al., 2006) and in the ocean were shown to be derived from thermogenic sources such as fossil fuel and biomass burning (black carbon; Kim et al., 2004), and to substantially contribute to active marine OM fluxes (Dittmar and Koch, 2006; Koch and Dittmar, 2006). Vanadyl porphyrins were identified in raw crude oil using FT-ICR-MS (Rodgers et al., 2001; Quian et al., 2008; McKenna et al., 2009). Moreover, the isolation of single ions in the ICR cell and their subsequent fragmentation is providing new insights into the molecular structure of single compounds (Witt et al., 2009).

All molecular FT-ICR-MS data published so far for natural OM samples from various regions and habitats are strikingly similar (Koch et al., 2005). It thus appears that the set of 
formulas detected in natural OM consisting of carbon, hydrogen and oxygen often covers almost all chemically feasible molecular formulas in the studied molecular size ranges (Hertkorn 2008). The similarity between the samples is in part derived by the selectivity of the extraction and ionization process. However, looking at the results of various ionization techniques, it can be reasonably hypothesized that the structure of humic substances is fundamentally determined by the predominant (selective) degradation mechanisms, and that the sources of OM are less crucial than expected. Based on the enormous diversity of molecular formulas observed for humic substances it also can be hypothesized that the preservation of this material is driven by its sheer complexity that inhibits energy efficient microbial degradation.

FT-ICR-MS has thus far proved most valuable in characterizing relatively polar macromolecules that are soluble in aqueous media and are amenable to electrospray ionization methods. A key challenge with respect to its utility in examining OM transformations and preservation will be its application to insoluble, and less polar macromolecular components that comprise a major fraction of the sedimentary particulate phase.

\subsection{Controls and preservation of soil derived $O M$ indicated by carbon isotopes}

Huge amounts of terrestrial organic carbon (OC) are exported from the continent to the ocean (Schlesinger and Melack, 1981) mainly as particulate and dissolved OC discharged by rivers, and also possibly via submarine groundwater discharge (Moore et al., 2008), thereby directly linking the terrestrial and marine carbon cycles. In the present-day environment, most of the OM that is discharged and is ultimately deposited in the ocean sediments accumulates in subaqueous deltaic systems and on shelf upper slopes of continental margins (Hedges and Keil, 1995). Much of this terrestrial OM appears to be highly degraded, and to derive from soils (Hedges et al., 1994). The predominantly marine nature of the OM accumulating in these depositional environments indicates that most $(>50 \%)$ of the soil OC is mineralized during its transport to, and within, the ocean (Hedges and Oades, 1997). Tropical mountainous river systems and rivers draining Arctic regions appear to be significant exceptions in terms of terrestrial OM export and burial efficiency (e.g., Hilton et al., 2008; Goñi et al., 2005). Overall, the fate of terrigenous $\mathrm{OM}$ in rivers and in the ocean, as well as the nature and fraction of the terrestrial organic carbon preserved in marine sediments, is poorly constrained.

A number of paleoenvironmental studies have examined the abundance and isotopic composition of terrigenous compounds deposited in marine sediments, particularly on higher plant lipids in the context of past climate variability (e.g. Schefuss et al., 2005; Smittenberg et al., 2006). These studies rely on the resistance of the biomarker compounds to degradation during their transport from the land to the ocean and within the sediment. Several investigations of organic compounds in soils and sediments, however, indicate compositional changes of $\mathrm{OM}$ during transport as well as in soils and marine sediments due to selective stabilization and degradation of organic compounds (e.g. Huang et al., 1999; Goñi et al., 2005; Mollenhauer and Eglinton, 2007). This can impart considerable changes in the abundance and isotopic composition of organic biomarkers in marine sediments, leading to a potentially misleading picture of terrestrial paleoenvironmental conditions. However, information on sources and transport processes affecting terrestrial $\mathrm{OM}$ composition are often based on studies of OM suspended and deposited in rivers as well as in margin sediments and thus consider only the second portion of the transport overall trajectory (e.g. Opsahl and Brenner, 1997; Bianchi et al., 2007). Specifically, OM degradation and transformations in soils require detailed investigation.

Soils are generally physically much more heterogeneous than sediments. Like surface sediments, soils are open systems where carbon is continuously added, lost and recycled (Gleixner et al., 2002). Hence soil OM consists of a vast number of organic compounds at various stages of decomposition and may contain carbon contributions from soil microorganisms, vegetation fires and fossil fuels (Czimczik and Masiello, 2007). Measured ${ }^{14} \mathrm{C}$ ages of various soil fractions and organic compounds, which range from years to several thousands of years, indicate different stability/turnover rates of these operationally defined carbon pools and provide information on soil OC protection mechanisms (Trumbore and Zheng, 1996; Rethemeyer et al., 2004).

Among the plant compounds considered to be resistant to microbial and enzymatic breakdown, lignin has long been suspected to be slowly biodegradable in soils due to its aromatic structure and non-hydrolysable intra-molecular bonds (Haider, 1992) and has hence been used as tracer for terrestrial OC supply to marine sediments (e.g. Hedges and Mann, 1979; Gough et al., 1993; Opsahl and Brenner, 1997; Goñi et al., 2005). Recent studies using ${ }^{13}$ C CPMAS-NMR and pyrolysis techniques however, have shown that in soils lignin is altered relatively quickly (e.g. Gleixner et al., 2002; Kiem and Kögel-Knabner, 2003). Lignin degradation in soil seems to depend on climatic conditions and vegetation cover (Otto and Simpson, 2006), and the phenolic subunits of lignin have been found to differ in their degradability/turnover rates, which decrease in the order: cinnamyl > syringyl > vanillyl (Bahri et al., 2006; Heim and Schmidt, 2007). Compoundspecific ${ }^{13} \mathrm{C}$ analyses of lignin phenols that were naturally ${ }^{13} \mathrm{C}$ labeled by $\mathrm{C}_{3}-\mathrm{C}_{4}$ crop succession were used to determine mean residence times of these compounds. In grassland and arable soils, the mean residence times of lignin-derived phenols were in the decadal range, faster than bulk soil OM turnover (Dignac et al., 2005; Heim and Schmidt, 2007). These observations question the assumed high resistance of these molecules against degradation. A similar result was obtained for long-chain $n$-alkanes from terrestrial plant-waxes 
extracted from arable soils that showed mean residence times of several years to decades, indicating no selective preservation during soil OM transformation (Wiesenberg et al., 2008; Marschner et al., 2008). The microbial recycling of presumably inert $\mathrm{OM}$ was furthermore indicated by depleted ${ }^{14} \mathrm{C}$ concentrations of individual microbe-derived phospholipid fatty acids isolated from a soil containing about $50 \%$ carbon mainly from lignite (Rethemeyer et al., 2004).

Several recent studies indicate that physicochemical interactions of $\mathrm{OM}$ with the mineral matrix play an important role in the preservation of soil organic carbon (Marschner et al., 2008 and ref. therein) as well as for marine sedimentary OM (Hedges and Keil, 1995; Keil et al., 1998). In soils the stability of organo-mineral associations varies, depending on grain- and aggregate-size but seems to be influenced by soil properties, management, and climatic conditions (von Lützow et al., 2007 and references therein).

These findings indicate the need to consider changes in $\mathrm{OM}$ and biomarker composition in soils when investigating terrigenous carbon fluxes to marine settings. There is relatively little information on the export of OM from soils into rivers and on compositional changes of the organic material. Terrestrial paleoenvironmental studies based on marine sediments could benefit from investigation of biomarker alteration on the entire transport trajectory from source to sink. Therefore, stable and characteristic molecular markers are needed in order to trace carbon from terrestrial plants. Because of the importance of physical OC stabilization processes in both marine and terrestrial environments, studies on selective stabilization and degradation of organic compounds in soils and sediments could be improved by bulk and compound-specific analyses of different physical (grain size, density) OM fractions. Redox conditions and the interplay of mixing by biological and/or physical processes in surface sediments are what seem to fine-tune the outcome. New lipid-based proxies of soil organic matter (e.g. Cooke et al., 2008; Weijers et al., 2006) may provide new ways to further explore soil OM inputs.

\subsection{Effects of animals on OM preservation and burial}

Most marine sediments are inhabited by a diverse community of protozoans and metazoans varying in size from few tens of $\mu \mathrm{m}$ to a few $\mathrm{dm}$. These organisms have a number of direct and indirect effects on sediment biogeochemistry and $\mathrm{OM}$ processing (Meysman et al., 2006). Direct effects of animals on OM processing include organic consumption, transformation and production by animals, while indirect effects relate to modifying textures, biodeposition, bio-irrigation, bioturbation and grazing on bacteria.

Burrowing organisms influence sediment properties such as porosity, permeability, compaction, glue particles together into aggregates upon egestion and tube building and segregate particles during digestion. These processes alter OMmineral-water interactions and thus the exposure of $\mathrm{OM}$ to hydrolytic enzymes and oxidants. Many benthic animals are suspension feeders that obtain their nutritional demands by filtering large quantities of water. These filter feeders are selective and the non-selected and non-assimilated materials are usually excreted and deposited as pseudo-faeces or faeces on the sediment surface. This biodeposition flux of OM can be very high in some systems with consequences for OM composition and preservation because of low oxygen, high sulfide conditions. Bio-irrigation and enhanced solute transfer are direct consequences of animal burrows. To supply oxygen and remove metabolites and toxic substances, benthic fauna actively flush their burrows with overlying water. Burrows therefore form a three-dimensional transport network that penetrates and irrigates the surrounding sediment tissue and deliver additional oxygen to deeper layers of sediments. Ventilation of animal tubes is often intermittent, with the consequence that sediment $\mathrm{OM}$ is subject to redox oscillation, which is known to stimulate OM degradation (Aller, 2001). Bioturbation, i.e. particle mixing due to animals, has multiple effects on OM processing: labile OM is transported to deeper layers where it may stimulate degradation of refractory OM ("priming") and partially degraded material may be transported upward to other redox zones. In mud, animals move forward via "cracking" and new surface is consequently steadily being produced (Dorgan et al., 2005). This will likely have major consequences for exposure and sorption (and thus degradation) of OM. Animals grazing on bacteria may affect microbial OM processing either positively by transporting labile organic matter to bacteria living at depth and in this way stimulating their growth or negatively by reducing biomass of active organisms (van Nugteren et al., 2009).

Animals are heterotrophic organisms and thus depend on $\mathrm{OM}$ for their energy. They directly consume a significant fraction of sediment OM (Moodley et al., 2005); part of this is assimilated and used for secondary production, another part is respired or defaecated. Secondary production of OM in marine sediments has been well studied by benthic ecologists and microbial ecologists (secondary bacterial production) and numerous biomarkers specific for animals and bacteria are known. However, there is no consensus whether secondary produced OM contributes significantly to the organic material that becomes eventually buried (Parkes et al., 1993; Sinninghe Damsté and Schouten, 1997). The overall effect of animals on sediment OM processing can most easily be quantified from the difference between diffusive oxygen uptake measurements and total oxygen uptake rates. While these numbers agree in deep-sea sediments, they diverge going from the deep-sea to coastal sediments (Glud, 2008), indicating that animals contribute significantly to OM processing in coastal sediments (Herman et al., 1999). 


\subsection{Physical factors affecting $\mathrm{OM}$ behaviour in marine environments}

There are several physical factors that influence burial. Because degradation usually involves enzymatic hydrolysis, temperature and pressure affect rates of (bio)chemical reactions, purely on kinetic grounds. Reduced temperature may inhibit enzyme activity, in part because the kinetics are slower and/or because bacteria may exhibit decreased affinity for substrates at lower temperatures. Macromolecularhydrolyzing enzymes may function equally well at higher or lower temperatures, but substrates produced by enzymes (as intermediates) might not be effectively taken up by the microbial community. Hydrolysis rates may be reduced at increased pressure that $\mathrm{OM}$ experiences as it sinks towards the sediments; however laboratory incubations designed to measure degradation rates often do not consider potential effects of pressure (see e.g. Arnosti et al., 2009 and references therein).

The mixing regime that $\mathrm{OM}$ experiences in surface sediments is important. Physical mixing (i.e., high turbulence during storm events) and biological mixing by macrorganisms (bioturbation) can irrigate sediments with oxygen, nutrients, and substrates, cause redox oscillations, or physically transport OM between redox zones, all of which effectively increase oxygen exposure (Fig. 1). Mixing or manipulations of particles by animals can cause particle fragmentation and alter particle surface areas, also enhancing exposure of OM to either hydrolytic enzymes or oxygen (Middelburg and Meysman, 2007).

Finally, there is now considerable discussion about how mineral surfaces or macromolecular organic matrices may protect OM from degradation (Fig. 2). Since all surfaces in aquatic systems are coated with some amount of OM, whether a monolayer equivalent, discrete patches of sorbed $\mathrm{OM}$, or OM within pores or interlayers of minerals (Arnarson and Keil, 2005, 2007) this OM may be physically protected from hydrolytic enzymes, although the exact mechanisms are unclear. Enzymes may be too large to access OM in pores or interlayers, but molecular oxygen or peroxides may be able to reach this OM. However, OM that appears to be "refractory" while associated with mineral surfaces may in fact be degradable once it is removed from the mineral surface. There is now sufficient reason to believe that the availability of mineral surface area places an important quantitative constraint on OM burial efficiency in sediments throughout the ocean (e.g. Hedges and Keil, 1995; Arnarson and Keil., 2001; Coppola et al., 2007). In addition to the protective role, these minerals may also serve a ballasting role in the oceanic water column (Armstrong et al., 2009). However, it appears to act only as a means of coarse adjustment. Finally, bioor geo-condensation processes can physically "encapsulate" otherwise "labile" OM into a protective macromolecular organic matrix.
Given the current state of knowledge, several important issues require further research. How valid are current experimental estimates of OM degradation rates given potential inhibitory effects by reduced temperature and increased pressure? There is a need to simulate degradation under insitu conditions. How does interaction with mineral surfaces actually protect $\mathrm{OM}$ from degradation? Do different mineral types (e.g., carbonate, opal, lithogenic material) intrinsically lead to differential preservation? What are effects of particle transport (size and density factors, winnowing and sorting, long-range transport to the deep ocean and drift deposits) on preservation?

\subsection{Degradation and transformation of organic matter (OM) in sediments.}

The previous sections each highlight selected aspects of the biological, physical and chemical factors influencing organic matter preservation. Clearly, there is interplay between these factors, and their relative importance varies spatially and temporally. Therefore, this section examines the interrelationships between these factors and their influence on OM degradation over various spatial and temporal scales (Fig. 3). Fed by photo or chemoautotrophic carbon fixation, particulate organic matter (POM) reaches the sea floor passively by sedimentation or actively by filter feeding animals. The material consists of many organic components that differ in quality, or reactivity, ranging from extremely labile (e.g. starch) to highly refractory (e.g. black carbon). For the purpose of this discussion, we simplify this to two categories: labile (LPOM) and refractory particulate organic matter (RPOM). The RPOM also includes labile organic matter which is intrinsically biodegradable but physically protected from biodegradation e.g. by encapsulation by or sorption to inorganic or organic particles. As degradation of OM particles progresses, compounds sorbed to, or protected by, these particles will become released. An equilibrium may exist between sorption/desorption depending on properties of the matrix, $\mathrm{pH}$, compound specific dissolution constants etc. Analogous to POM, dissolved OM (DOM) is comprised of both refractory (RDOM) and labile (LDOM) components that span a range of OM quality (for simplicity the refractory portion is included in RPOM in Fig. 3 as "ROM"). In sediments, LDOM is considered to be mostly composed of small organic molecules resulting from extracellular enzymatic activity and cell lysis.

In the uppermost, oxic portion of the sediment column, degradation is relatively fast, decreasing in an exponential fashion as the residual organic matter becomes increasingly recalcitrant. Some of this $\mathrm{OM}$ is transferred from the oxic zone by biodegradation and bioturbation into the underlying anoxic zone. There is also an upward migration of the anoxic zone as sedimentation proceeds. The organisms responsible for OM degradation include bacteria and archaea, as well as unicellular and multicellular eukaryotes 


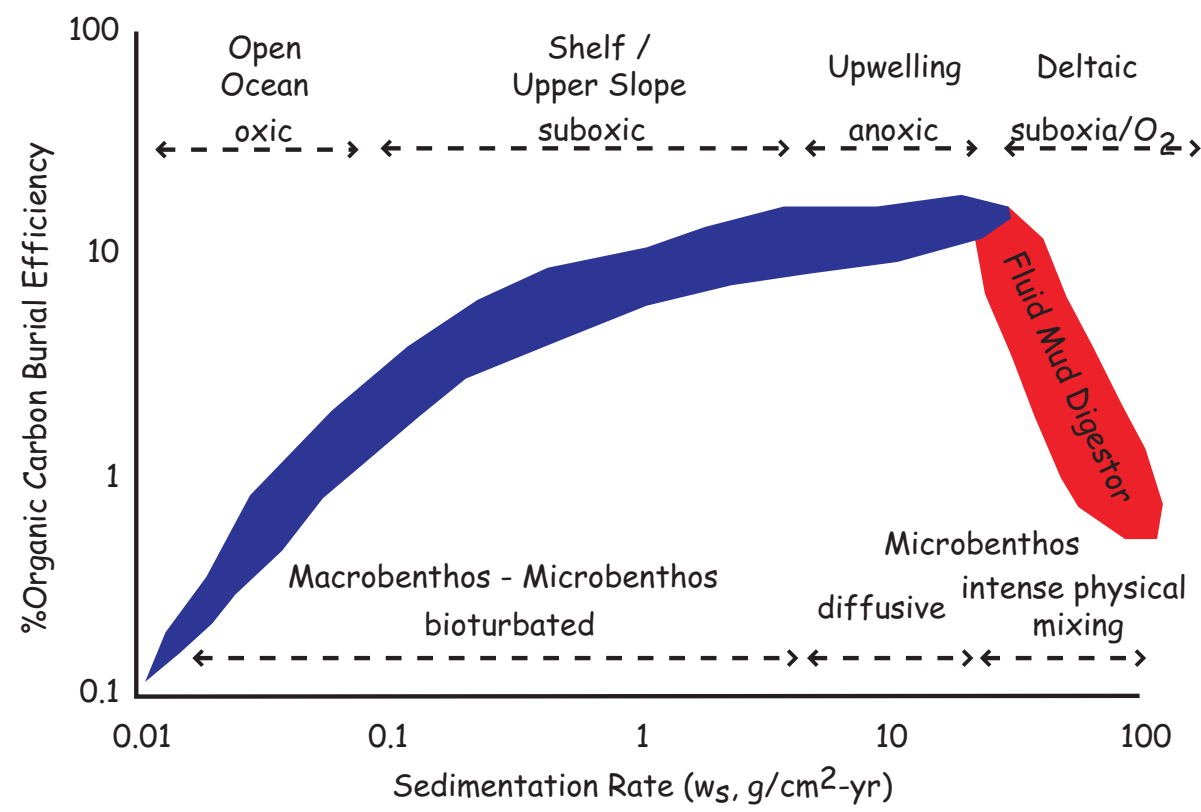

Fig. 1. Cartoon illustrating the complex, multivariate nature of the biological and/or physical processes in surface sediments fine-tuning the organic matter burial efficiency in different marine sedimentary settings.
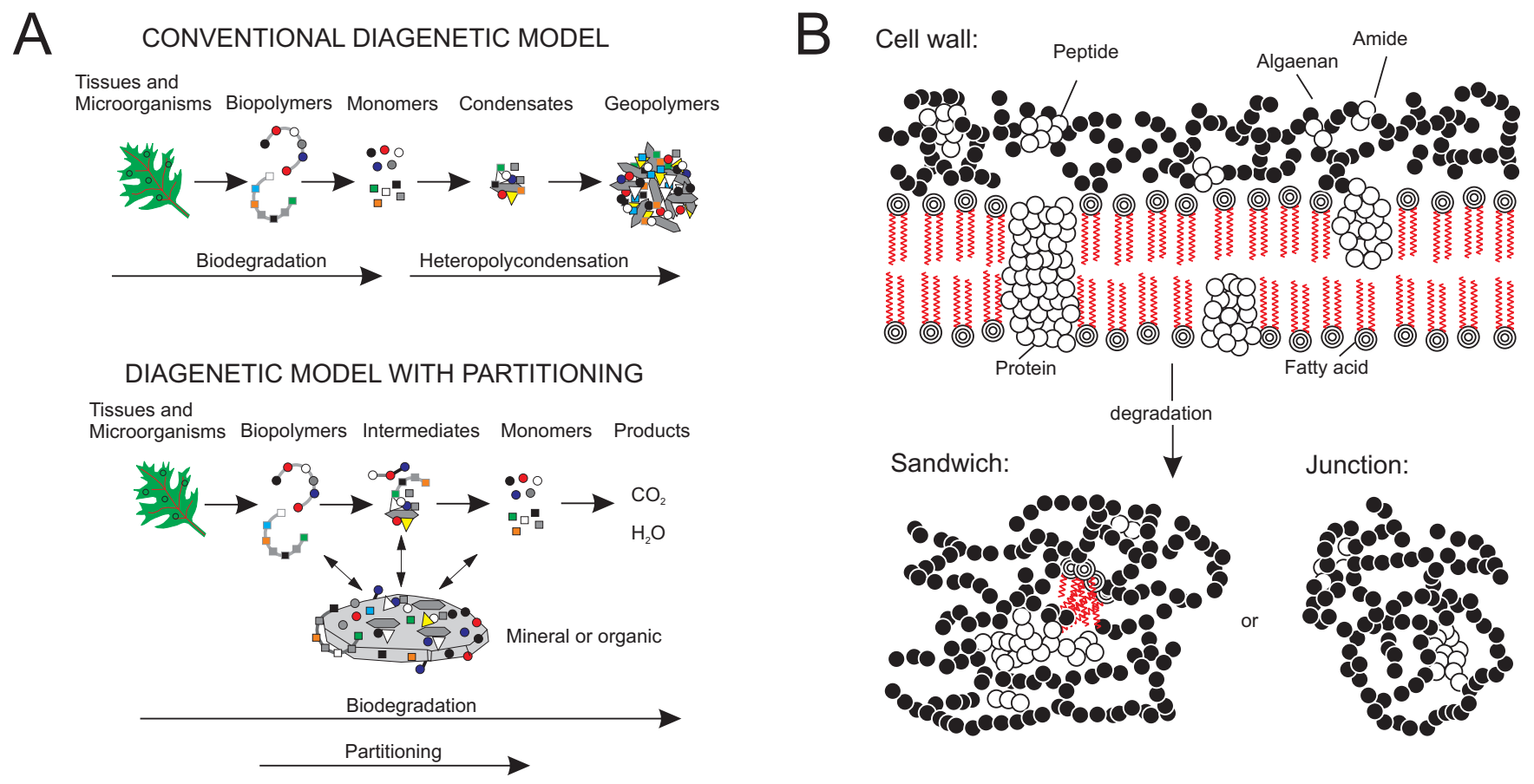

Fig. 2. Physical protection of organic matter. (A) Conventional biodegradation/repolymerisation model (top) and alternative biodegradation/sorption model for organic matter diagenesis and preservation (bottom) (modified from Hedges and Keil, 1999). (B) Schematic illustrations of (above) the structure of an algaenan-containing cell wall and (below) proteinaceous organic matter "encapsulated" within degraded algal cell wall material (modified from Knicker and Hatcher, 2001) 


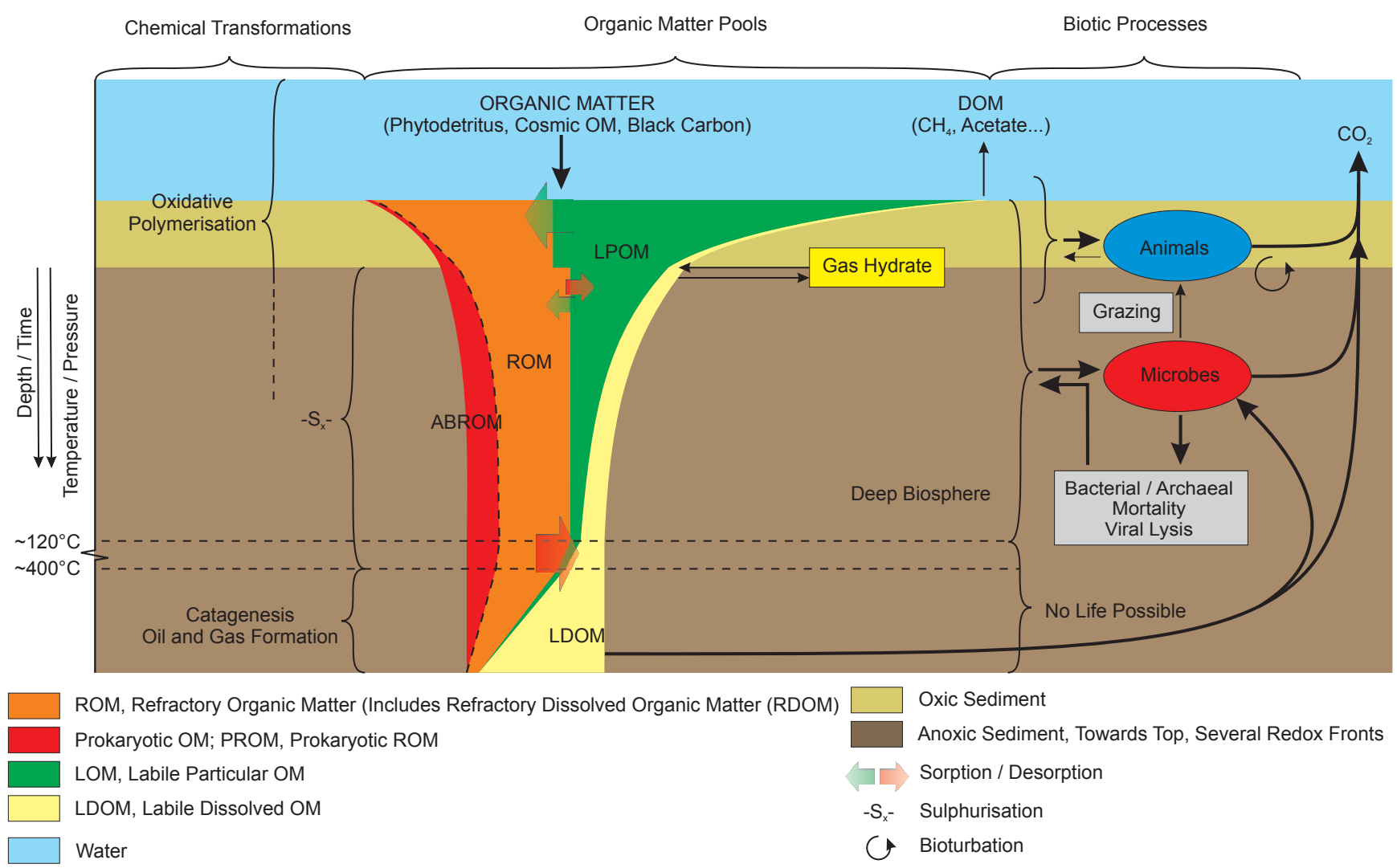

Fig. 3. Degradation and transformation of organic matter $(\mathrm{OM})$ in sediments. Left, chemical transformation processes; Centre, organic matter pools; Right, biotic processes. The sizes of the organic matter pools and their size reduction with time/depth underestimate the actual degradation, they are not in scale but indicate processes and relative changes (For further explanation see Sect. 2.6).

(e.g. ciliates, worms). The bacteria and archaea are grazed by eukaryotes and are also subject to (viral) lysis. The resultant DOM is mostly consumed by microbial activity but a small portion of the OM derived from bacterial and archaeal likely accumulates and is preserved as ABROM in the sediments (see Parkes et al., 1993).

Eukaryotes generally occupy only the uppermost sediment layers but may return $\mathrm{OM}$ from the underlying anoxic regions to the oxic zone via bioturbation. The uppermost layers within the anoxic zone of sediments includes a succession of redox-zones and associated microbial consortia, each consuming and producing characteristic types of organic matter (e.g. Froelich et al., 1979; Canfield and Thamdrup 2009). There is a decreasing available redox potential and associated energy gain upon OM degradation across these zones. As a result, biotransformation rates slow down (symbolised by an angle in the change in pool size with depth at the oxic/anoxic interface in Fig. 3). Ultimately, some biochemical transformations are no longer energetically favourable, with the result that $\mathrm{OM}$ requiring these transformations for digestion is effectively transferred from the labile to the refractory OM pool (symbolised by the step-change in ROM/LPOM pool sizes at oxic/anoxic interface in Fig. 3) resulting in its ac- cumulation in the underlying sediments. This reduction in biodegradative potential also results in accumulation of small organic (LDOM) and inorganic molecules (e.g. $\mathrm{CH}_{4}$, acetate, $\mathrm{H}_{2} \mathrm{~S}$ ). These may either migrate upwards to be consumed in a zone with more favourable redox conditions or to escape to the water column. Depending on pressure and temperature, produced $\mathrm{CH}_{4}$ may be removed from the LDOM pool as gas hydrate (or released from it) or escape from the sediment. The accumulating small compounds (e.g. acetate) may also change the $\mathrm{pH}$ of the sediment, concomitantly changing sorptive and stereo-specific properties of the organic matter and surrounding sediment. This, in turn, can release or remove compounds for biodegradation/chemical transformation. Free sulphur species released as a consequence of biochemical processes may induce polymerisation of the organic matter by sulphurisation transferring LPOM (and LDOM) to the ROM pool. The depth-related decrease in redox potential also reduces the efficiency of the oxidative polymerisation pathway.

Overall, in this zone as well as the overlying oxic zone, the relative proportion of refractory organic matter (ROM+ABROM in Fig. 3) increases over time since (1) biodegradation rates decrease with decreasing OM quality, 

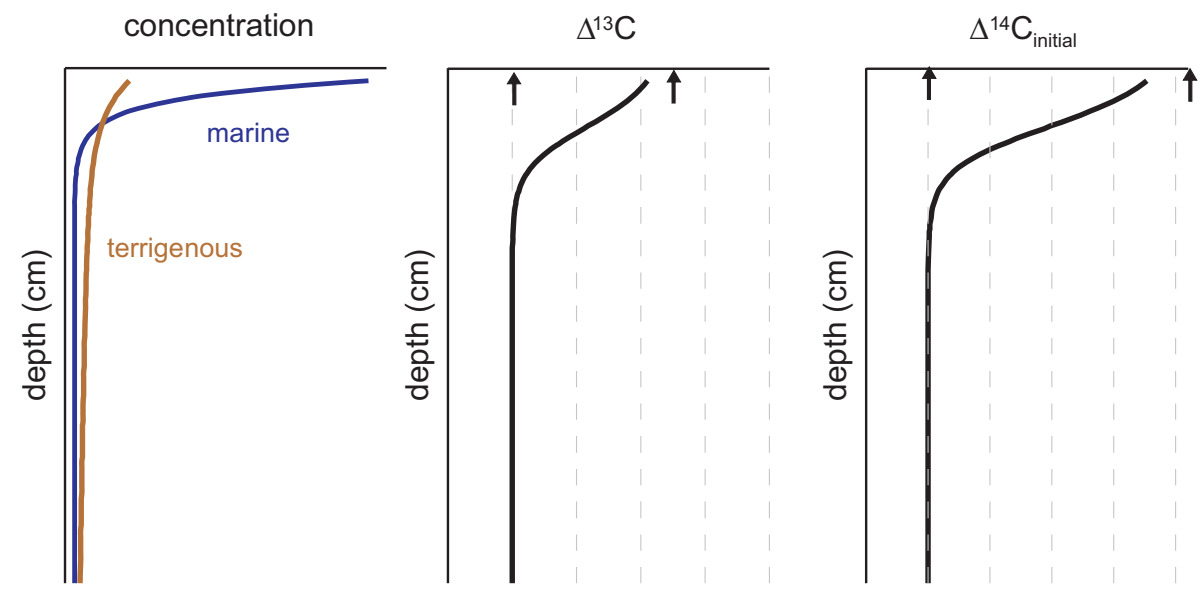

Fig. 4. Conceptual diagram illustrating down-core profiles in relative concentration of a compound that can be derived both from marine and terrestrial sources. If the materials from the two sources differ in stable isotopic and radiocarbon signatures, the more rapid decay of the marine component would result in $\delta^{13} \mathrm{C}$ and $\Delta^{14} \mathrm{C}$ profiles as illustrated. Arrows indicate assumed isotopic composition of the marine and terrigenous components.

(2) oxidative polymerisation, and in the anoxic zone also sulphurisation, transfer labile organic matter towards the refractory pool, and (3) part of the archaeal and bacterial organic matter produced in the sediment (ABROM) can't be degraded.

With increasing depth, temperature and pressure $(\mathrm{P} / \mathrm{T})$ increase. This may speed up the chemical polymerisation processes and may also cause desorption of biodegradable material feeding the deep biosphere. Although above a given temperature life becomes impossible, chemical transformation continues. As a result of these processes the LOM and LDOM pools should decrease. However, migration of DOM from the zone below may (as in Fig. 3), but doesn't need to counterbalance this process.

Above a critical combination of $\mathrm{P} / \mathrm{T}$ conditions, fragmentation of the $\mathrm{OM}$ exceeds polymerisation. The cracking of the organic matter leads to DOM (including also liquid hydrocarbon phases) and $\mathrm{CO}_{2}$ which sooner or later become bioavailable by migration into the (deep) biosphere. Possible ways include by direct upwards migration through the sediment, migration with the sediment following the sedimentary cycle(s) of rock formation and erosion and/or by ingestion into the mantle and subsequent volcanic or plutonic activity.

It must be kept in mind that the processes described above are not only selective at molecular level but also at the level of atoms, shifting isotopic compositions. Furthermore, it is important to realise that the physical, chemical and biological properties of the sediment not only determine organic matter preservation and degradation, but that this is also true in the opposite direction e.g. through modifying the mineral composition by dissolving carbonate. Understanding both the selectivity and sediment-modifying capability of the organic degradation/transformation is important, since these processes imply modification of organic and inorganicmatter based sediment-derived proxies, which has consequences for the way we reconstruct Earth history.

\section{The interpretation of several lipid-based marine proxies}

\subsection{Selective degradation as deduced from radiocarbon measurements}

It has been known for a long time that rapid organic carbon degradation occurs in the uppermost centimetres of marine sediments, and that concentrations of individual compounds decrease at compound-specific rates (Sun and Wakeham, 1994; Wakeham and Canuel, 2006) within a certain setting. However, down-core concentration profiles of many organic compounds asymptotically approach a more or less stable background value below the uppermost few centimetres of the sediment. A simple model to explain this observation requires that the sum of a given organic compound is composed of (at least) two components with different reactivities, and the relative contribution of the more reactive component decreases with increasing degree of degradation. While different degradation rates between different biochemicals are readily explained, it is not well understood where the less reactive component originates, how old it is, or why it is protected from degradation.

For components that originate from different sources with distinct stable isotopic signatures and different transport- and intermediate residence times before deposition on the seafloor, the preferential preservation of one component over the other should result in down-core profiles as illustrated in Fig. 4. Carbon isotopic $\left(\delta^{13} \mathrm{C}\right.$ and $\left.\Delta^{14} \mathrm{C}\right)$ data show that 

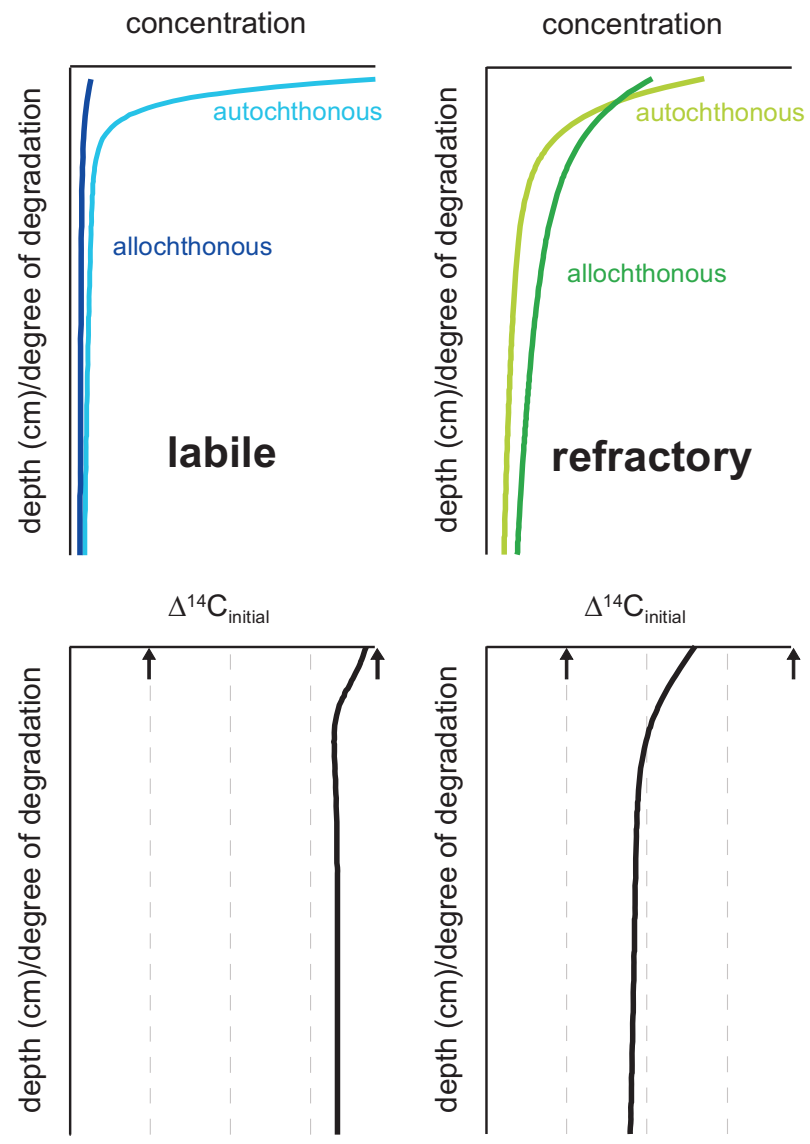

Fig. 5. Conceptual diagram illustrating the effect of preferential degradation of autochthonous, unprotected material on $\Delta^{14} \mathrm{C}$ profiles of two marine compounds with different decay rates.

for short-chain $n$-alkanoic acids (e.g., $\mathrm{C}_{16: 0}$ ), occurring ubiquitously both in marine and terrestrial environments, the terrigenous component is better preserved in marine sediment. Moreover, this terrigenous component is often pre-aged at the time it is buried (Mollenhauer and Eglinton, 2007).

When molecular biomarkers exclusively from marine sources are considered, preferential preservation of a less reactive component, if supplied via lateral advection of preaged material, can be detected if their radiocarbon contents are lower than expected. An example would include lower radiocarbon values for phytoplankton-derived biomarker lipids (e.g. alkenones) relative to those of co-occurring near-surface dwelling planktic foraminifera (Ohkouchi et al., 2002). This may be particularly evident when comparing depositional environments with identical input but contrasting levels of oxygenation such as flank and depo-center sediments from Santa Monica Basin (Mollenhauer and Eglinton, 2007).

Differences in preservation potential of plankton-derived biomarkers with different pre-depositional histories found in the same sediments would be expected to result in characteristic radiocarbon concentrations along gradients reflecting their increasing extent of degradation (Fig. 5). This

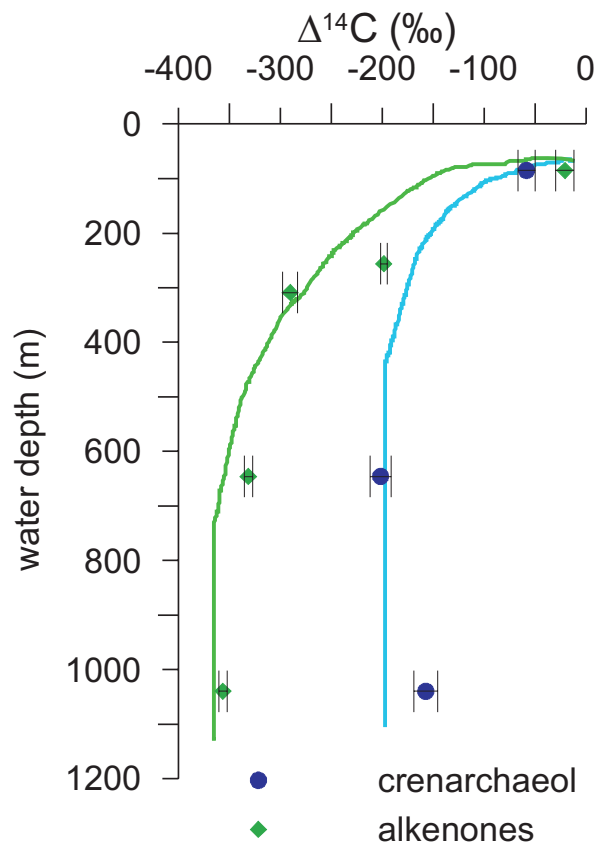

Fig. 6. Radiocarbon concentrations of alkenones and crenarchaeol in core-top samples along an offshore transect across the Namibian Shelf and slope (Mollenhauer et al., 2007). Lines are hand-drawn and suggest more rapid degradation of crenarchaeol than alkenones.

could be observed either over down-core profiles or along transport trajectories. Radiocarbon concentrations of two plankton-derived organic biomarkers, alkenones and the archaeal membrane lipid crenarchaeol, in core-top sediments along a transect across the Namibian shelf agree with this concept (Fig. 6) (Mollenhauer et al., 2007). These data suggest that crenarchaeol is less likely to be preserved during transport in oxygen-replete waters. The reasons for the enhanced preservation of alkenones during lateral transport remain unclear. The role of mineral association should be investigated in this context.

Taking into account the observations described above, biomarkers preserved in marine sediment must be considered a distributed property. In other words, a sample consists of mixed populations of components from a multitude of sources and with variable radiocarbon signatures. These mixed age populations may result not only from marine components or via water column processes. For example, terrestrial biomarkers supplied by rivers and atmospheric deposition likely comprise fresh and soil-derived (aged) components. The radiocarbon concentration measured in one sample can consequently be expressed according to a mixing equation as described in Pearson and Eglinton (2000):

$\Delta^{14} C_{i j}=\Sigma_{k} X_{i j} W_{i k} \Delta{ }^{14} C_{i j k} / \Sigma_{k} X_{i j} W_{i k}$

where $W_{k}=$ fraction of carbon derived from source $k ; X_{i}$ $=$ fraction of total carbon in source $W$ that belongs to biomarker $i ; j=$ sample. 
In order to interpret biomarker data, the terms $W, X$, and the respective $\Delta^{14} \mathrm{C}$ of the individual components should be known, as well as the number of sources contributing. Independent methods to estimate lateral input would be desirable. To date, the contribution of allochthonous material can only be estimated assuming end-members, and the number of contributing sources allowing for unambiguous solutions is typically limited by the number of independent compoundspecific isotope data (typically $\delta^{13} \mathrm{C}$ and $\Delta^{14} \mathrm{C}$, cf. Pearson and Eglinton, 2000). A second major piece of information that is typically lacking is the provenance of the laterallyadvected components. When studying terrigenous biomarkers in marine sediments, soil and dust sources within the hinterland should be investigated. For marine biomarkers, areas of sediment re-suspension or erosion must be identified upstream or upslope from the site of deposition.

\subsection{Selective lipid degradation}

In recent years, biomarker ratios have been proposed as indices to gauge changes in sedimentary redox conditions through time. Sinninghe Damsté et al. (2003) coined the ratio of lycopane (a biomarker of presumed marine photoautotrophic origin) to $n-\mathrm{C}_{31}$ alkane (a biomarker of vascular plantwax origin) as such an index. The integrity of this proxy was tested in modern sediments spanning the oxygen minimum zone (OMZ) in the Peru Upwelling region. Values appeared higher in sediments deposited within the OMZ than in those deposited under less reducing, perhaps oxic, conditions at both shallower and deeper depths. Given that the relative flux of both biomarkers to the seabed was relatively constant throughout the region, the response of the index was consistent with what is now known about the relative diagenetic stability of phytoplankton versus terrestrial-derived biomarkers (Prahl et al., 2003). Although the assumption of a constant, proportional flux into the seabed was argued as justifiable in the case of the modern Peru Upwelling Zone, this assumption is difficult, if not impossible, to assess objectively in the paleoenvironment. Consequently, stratigraphic variations in the ratio of lycopane: $n-\mathrm{C}_{31}$ alkane may provide a gauge of changes in sedimentary redox conditions, however such inferences could not be made unequivocally. It could also depict a change in the relative source strength under otherwise very comparable redox conditions at the seabed. How could these two prospects be differentiated objectively? Ideally, one could use multiple (organic and inorganic) parameters with differing sensitivities to other factors. Cacho et al. (2000) coined the ratio of a long-chain n-alcohol $\left(\mathrm{C}_{26}\right.$-ol $)$ to $n$-alkane $\left(\mathrm{C}_{29}\right)$ as another biomarker index of sedimentary redox conditions. In this case, both compounds are derived from a terrestrial source. The assumption is that both derive from a common terrestrial source where the ratio is fixed at some constant value and the $\mathrm{C}_{26}$-ol has greater sensitivity to decomposition than the $n-\mathrm{C}_{29}$ alkane when this source material is deposited under oxic conditions. Hence, values of

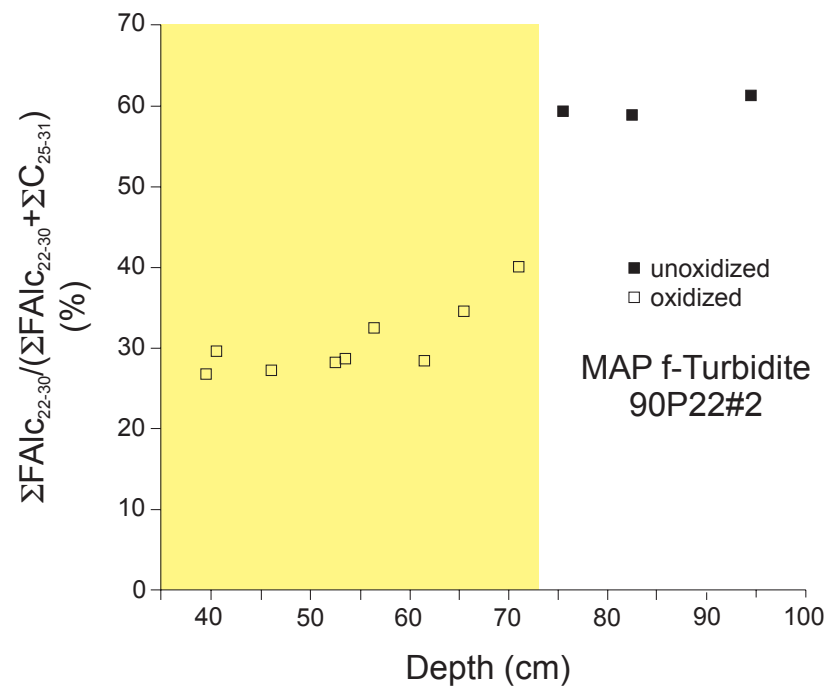

Fig. 7. Results from study of an aerobic burndown turbidite on the Madeira Abyssal Plain (Prahl, unpublished) which supports the inferred sensitivity of the long-chain $n$-alcohol $\left(\mathrm{C}_{26}\right.$-ol $)$ to $n$ alkane $\left(\mathrm{C}_{29}\right)$ diagenetic index proposed and employed by Cacho et al. (2000).

the ratio become increasingly reduced as environmental conditions become more oxic, and vice versa.

Study of an aerobic burndown turbidite on the Madeira Abyssal Plain has yielded an observation corroborating the inferred diagenetic sensitivity of this index (Fig. 7). However, as with the lycopane: $n-\mathrm{C}_{31}$ index, it poses a significant challenge to objectively determine whether or not quantitative variations observed in this terrestrial plantwax index (e.g. Martrat et al., 2007) are solely driven by redox conditions at the seabed.

In summary, lipid biomarkers now provide the paleoceanographic community with invaluable "eyepieces" for evaluation of environmental and climatic change. Nonetheless, these tools would all benefit from continued effort to improve their focus and remove "chromatic aberrations". Diagenetic factors do indeed act to blur the signals we aim to glean from stratigraphic records of specific biomarkers in sediments. Concerted research efforts in the future should help us to identify and clarify the exact nature of these complications and to devise objective methods or measurement strategies, to extract accurate information about paleoenvironmental and climatic conditions.

\subsection{The $U_{37}^{K^{\prime}}$ paleothermometer and the impact of degradation}

Downcore stratigraphic records for $\mathrm{C}_{37}$ alkenone concentration have been employed as an gauge for paleoproductivity change (Prahl and Muehlhausen, 1989; Villanueva et al., 1998; Schulte et al., 1999). Although conceptually quite reasonable, comparisons of sediment trap and sediment pairs 


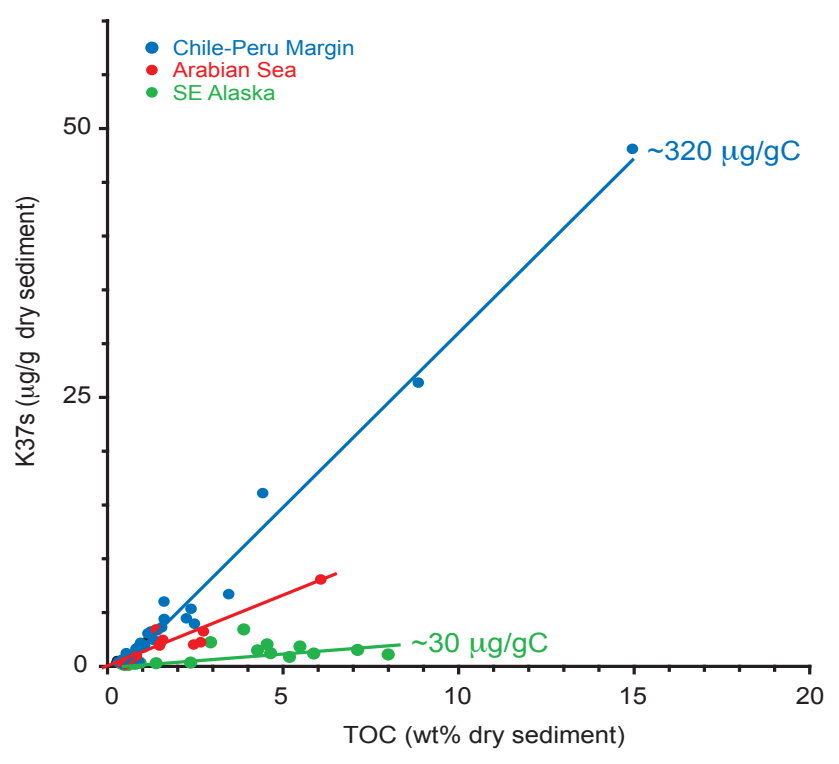

Fig. 8. Results from analysis of alkenones in surface sediments from three very different oceanographic environments (coastal region off SE Alaska (Walinsky et al., 2009) continental margin off Chile-Peru (Prahl et al., 2006), Oman margin and open Arabian Sea) (unpublished).

for the NE Pacific Ocean (Prahl et al., 1993) and the Arabian Sea (Prahl et al., 2000; Wakeham et al., 2002) showed that diagenetic processes at the seabed can completely invert the perspective on productivity of alkenone-producers and their contribution to total phytoplankton-derived OM. Thus, results from this stratigraphic application must always be interpreted cautiously (e.g. Hedges and Prahl, 1993)

In the NE Pacific Ocean study (Prahl et al., 1993), redox conditions in bottom sediments along the offshore transect varied widely, grading from iron-reducing to manganesereducing to oxic. Quite possibly, distortions in apparent biological productivity in down-core records may not occur in sedimentary environments characterized by more subtle variations in redox conditions. In this circumstance which may be more relevant to a specific marine sedimentary location, the direction of change is perhaps reliably indicated, whereas the magnitude of change would remain uncertain.

Figure 8 shows results from analysis of alkenones in surface sediments from three very different oceanographic environments (coastal region off SE Alaska - (Walinsky et al., 2009), continental margin off Chile-Peru - (Prahl et al., 2006), Oman margin and open Arabian Sea - unpublished data). Data from each environment appear to plot along lines characterized by distinct slopes. Although diagenesis may to some extent be a factor shaping these observations, it seems most likely that these lines convey information about the average phytoplankton ecology of surface waters in each region (Prahl et al., 2006; Walinsky et al., 2009). Alkenoneproducing coccolithophorids (De Vargas et al., 2007) are ma- jor contributors in surface waters of the Chile-Peru margin relative to the case for coastal waters of SE Alaska where biogenic silica-rich sediments indicate that diatom contributions dominate. More detailed research is clearly warranted to determine:

1. how other lipid biomarkers of phytoplankton origin besides the alkenones are impacted under variable redox conditions and subsequently,

2. the reliability of using biomarker ratios to ascertain the impact of climate change on phytoplankton community structure in surface waters (Prahl, 1992).

Since the first report that alkenone unsaturation patterns provide a viable tool for the reconstruction of past sea-surface temperatures (SST) (Brassell et al., 1986), this molecular proxy has been employed widely and, in general, with tremendous success (Herbert, 2003). Nonetheless, we have also learned in this $\sim 20 \mathrm{yr}$ period that $\mathrm{U}_{37}^{K^{\prime}}$ values are not strictly set by the growth temperature of the alkenoneproducers (see also Eglinton et al., 2001 and related papers). Non-thermal physiological factors such as nutrient stress and light availability, can significantly impact unsaturation patterns and potentially their paleoceanographic interpretation (e.g. Versteegh et al., 2001; Laws et al., 2001; Prahl et al., 2006). Although the bias caused by these non-thermal physiological effects appears to be in a systematic direction, it is not yet clear how to recognize unambiguously when such bias has occurred and, if so, how to quantitatively account for it.

Early studies both in a natural field setting (Prahl et al., 1989) and in the laboratory with bacterial cultures (Teece et al., 1998) showed $\mathrm{U}_{37}^{K^{\prime}}$ values, once set by the alkenoneproducer, are relatively insensitive to alteration despite major reductions in abundance of these biomarkers as a consequence of aerobic decomposition. Nonetheless, significant shifts to more positive values, albeit often small, were apparent in results from the early field work (e.g. Hoefs et al., 2002) and more recently from an experimental field study (Kim et al., 2009). Laboratory work with mixed bacterial populations (Rontani et al., 2008) and field observations (Rontani and Wakeham, 2008) have shown that some consortia of aerobes can degrade alkenones selectively, leading to positive shifts in $\mathrm{U}_{37}^{K^{\prime}}$ equivalent to a $\sim 2$ to $3^{\circ} \mathrm{C}$ increase in growth temperature. Interestingly, in experiments where such $\mathrm{U}_{37}^{K^{\prime}}$ shifts have been observed, oxidation products indicating selective decomposition of the alkenone double bonds were detected. Such products were not detectable in experiments where alkenones were degraded by aerobic microbial consortia without impact on $\mathrm{U}_{37}^{K^{\prime}}$.

While alkenones have become established as a valuable tool for SST reconstruction, in some circumstances $U_{37}^{K^{\prime}}$ data disagrees with those from other SST proxies, such as those derived foraminiferal transfer functions or $\mathrm{Mg} / \mathrm{Ca}$ ratios. Under these circumstances, the question arises as to which 
proxy provides the accurate assessment. To unravel this, the effects of selective preservation and differences in ecologies of the proxy carrying organisms need to be assessed. We now recognize that selective, aerobic decomposition of alkenones, which can lead to a positive shift in $\mathrm{U}_{37}^{K^{\prime}}$ of some significant magnitude, yields distinctive metabolic products. Examination of sediment samples yielding 'questionable' $\mathrm{U}_{37}^{K^{\prime}}$ results for the presence of these metabolic products provides an objective (but yet largely unexplored) way to determine if aerobic diagenesis could provide at least some explanation for disagreement in SST assessments. It is likely, however, that these metabolites are themselves degradable (especially since they are more polar), so their presence/absence may not be particularly definitive.

As briefly described above, we also now know that redox conditions play a role in quantitatively setting the burial efficiency for biomarkers. Although burial efficiency more than likely displays the same general pattern for all biomarkers, declining as sedimentary conditions shift from anaerobic to aerobic, much remains to be learned about the specific quantitative relationship between burial efficiency and redox conditions for different biomarkers. Currently, we know that biomarkers do not behave the same diagenetically (Wakeham et al., 1997; Prahl et al., 2000). However, more detailed understanding of the specific quantitative relationship for individual biomarkers will clearly be necessary if we want to confidently reconstruct, oceanographic details such as the sensitivity of phytoplankton community structure to climate change (Hedges and Prahl, 1993) based on examination of downcore stratigraphic records for biomarker ratios.

\subsection{The impact of degradation on glycerol dialkyl glycerol tetraethers and the $\mathbf{T E X}_{86}$ paleothermometer}

The preservation of organic carbon (OC) is strongly dependant on, amongst other factors, the oxygen exposure time (OET), generally more OC is degraded with longer oxygen exposure time (Hartnett et al., 1998, Hedges et al., 1999). Bulk OC, long-chain alkenones and glycerol dialkyl glycerol tetraethers (GDGTs) were analysed in oxidized and unoxidized layers of a selection of organic-rich turbidites deposited at the Madeira Abyssal Plain MAP (Huguet et al., 2007, 2008, 2009). These distal, fine-grained, turbidites contain OM that first accumulated on the continental margin and was subsequently displaced and redeposited in the abyssal plain. Once redeposited, the upper part of such relatively homogenous sedimentary units were exposed to oxygenated bottom water, leading to oxidation fronts progressing downward until deposition of the next turbidite occurred. As a consequence of this downward oxidation, concentrations of OC, GDGTs and alkenones were reduced by one or two orders of magnitude in the oxidized upper parts of the turbidites indicating substantial degradation compared to the un-oxidized lower parts (Fig. 9; Huguet et al., 2008 and references therein). Results from the MAP F-turbidite clearly show that there is a sharp decrease of both GDGTs and $\mathrm{C}_{37}$ alkenones in the oxidized part of the turbidites and are thus severely degraded upon long-term exposure to oxygen (Fig. 9). This is in agreement with previous studies that showed that GDGTs (Schouten et al., 2004) and alkenones are degraded under (sub)oxic conditions (Prahl et al., 2003).

While the abundances of the measured isoprenoid GDGTs substantially decrease in the F-turbidite from ca. $4 \mu \mathrm{gg}^{-1}$ sediment in the anoxic part to $0.1 \mu \mathrm{g} \mathrm{g}^{-1}$ sediment at the upper oxic part (Fig. 9) in agreement with previously reported results for crenarchaeol (Huguet et al., 2008), this decrease is less substantial for the branched GDGTs. As a consequence, the BIT index shows an increase from the anoxic to the oxic part i.e. from 0.03 in the anoxic to 0.45 in the oxic part of the F-turbidite (Fig. 9; Huguet et al., 2008). There may be several reasons for the enhanced preservation of branched GDGTs. The branched GDGTs could be chemically more resistant against degradation than isoprenoid GDGTs. However, it is difficult to envisage why polar lipids with branched carbon skeletons should be degraded slower than isoprenoid carbon skeletons as degradation is likely to start at the functionalized glycerol moiety. Moreover, it has generally been observed that branched alkyl chains are more easily degradable than isoprenoid chains (Hanford and Peeples, 2002). The results can be better explained by the different origins of the branched GDGTs and isoprenoid GDGTs, i.e. soil derived matter versus marine derived matter. The preferential preservation of terrestrial versus marine organic organic compounds, and of OC in general, has been observed before (e.g. Burdige, 2005). However, up to now it was not possible to assess whether this preferential preservation was due to the chemical structure of the terrestrial OM, or because some attribute of the mineral matrix protects it from degradation. These results suggest that the matrix to which soil $\mathrm{OM}$ is attached enhanced their preservation (Huguet et al., 2008).

Besides having a general impact on OC preservation, aerobic degradation may also affect the relative distribution of biomarker lipids. Studies of sediments deposited in the MAP (Hoefs et al., 2002) and in the Arabian Sea (Sinninghe Damsté et al., 2002) showed that post-depositional aerobic degradation not only decreased the concentration of lipid biomarkers by several orders of magnitude, but also that the extent of the degradation was different for different compounds and thus may cause a severe bias in the biomarker distribution. An important effect of this bias is the impact it may have on organic paleoceanographic proxies such as $\mathrm{U}_{37}^{K^{\prime}}$, $\mathrm{TEX}_{86}$ and the branched and isoprenoid tetraether (BIT) index (the latter a proxy for soil organic carbon in sediments, Hopmans et al., 2004). A previous study in the Arabian Sea comparing oxidized and un-oxidized samples showed no significant differences in $\mathrm{TEX}_{86}$ (Schouten et al., 2004) and similar results were obtained from an experimental field study, setting out a sediment sample from the Namibian shelf 


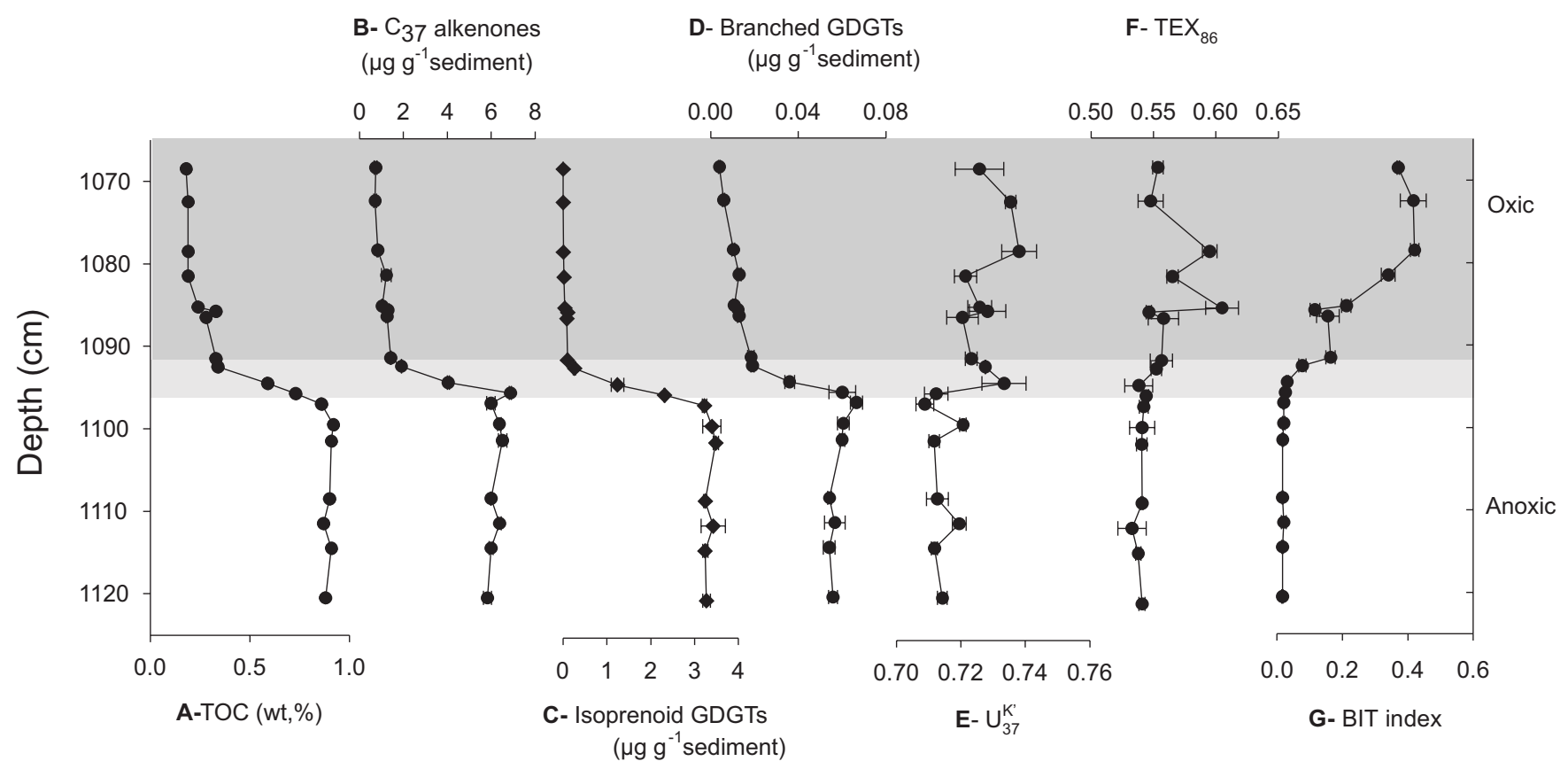

Fig. 9. Profile of (A) TOC (wt. \%), (B) $\mathrm{C}_{37}$ alkenones abundance ( $\mu \mathrm{gg}^{-1}$ sediment), (C) summed abundance of isoprenoid ( $\mu \mathrm{g} \mathrm{g}^{-1}$ sediment), (D) Branched GDGTs abundance ( $\mu \mathrm{gg}^{-1}$ sediment), (E) $\mathrm{U}_{37}^{K^{\prime}}$ (F) TEX 86 , and (G) BIT index across the oxidation front in the F-turbidite (Huguet et al., 2008).

on moorings in oxic and anoxic waters (Kim et al., 2009). However, the exposure times to oxygen in these latter studies were very short $(1 \mathrm{yr})$ compared to those in the F-turbidite at the MAP ( $>100 \mathrm{kyr}$ ).

In the case of the F-turbidite both the $\mathrm{TEX}_{86}$ and $\mathrm{U}_{37}^{K^{\prime}}$ show a positive shift in the oxic layer of the turbidite (Huguet et al., 2009). With respect to $U_{37}^{K^{\prime}}$ these results suggest a preferential degradation of the $\mathrm{C}_{37: 3}$ alkenone, in agreement some prior observations (Hoefs et al., 1998; Gong and Hollander, 1999; Kim et al., 2009) and indicates a small but significant effect of diagenesis on this temperature proxy. The observed shift in $\mathrm{TEX}_{86}$ also suggests that oxic degradation affects this SST proxy.

The cause of the observed shifts in $\mathrm{TEX}_{86}$ values may result from the preferential preservation of soil-derived GDGTs. Weijers et al. (2006) showed that besides branched GDGTs, isoprenoid GDGTs also occur in soils in varying and relatively small amounts and that this can affect marine $\mathrm{TEX}_{86}$ values if there is a large input of soil OM. In the anoxic part the contribution of terrestrial GDGTs is relatively minor as evidenced by the low BIT values $(<0.1)$, and thus the $\mathrm{TEX}_{86}$ values are almost exclusively determined by isoprenoid GDGTs from marine sources. In the oxidized zone of the turbidites, however, the marine derived GDGTs are degraded to a larger extent than soil derived GDGTs because of matrix protection (Huguet et al., 2008) and thus the $\mathrm{TEX}_{86}$ value may be substantially influenced by isoprenoid GDGTs derived from the continent (Huguet et al., 2009). Thus, the effect of aerobic degradation on the $\mathrm{TEX}_{86}$ will depend on the composition of isoprenoidal GDGTs derived from the continent in the original turbidite sediment compared to that in the marine environment and our results suggest that this may vary substantially. Therefore, care should be taken when interpreting $\mathrm{TEX}_{86}$ in sediments which have been exposed for a long time to oxygen. This bias may be assessed by cross-correlating BIT indices with $\mathrm{TEX}_{86}$ : a high degree of correlation between the two proxies may signify a substantial bias.

\section{Past productivity and (selective) OM degradation}

As discussed above, elucidating the processes related to (selective) OM degradation is essential for an accurate interpretation of proxy records and characterizing the dynamics of the sedimentary carbon pool also contributes to understanding the biogeochemical cycle of carbon. A proper reconstruction of degradation intrinsically also leads to assessment of past export productivity, another important aspect of the carbon cycle that is critical to carbon preservation. Therefore, this chapter deals with quantification of past productivity in relation to selective degradation.

\subsection{Barium as a paleoproductivity proxy/tracer}

In oxic, open-ocean settings the diagenetic overprint on OM is often a major problem for estimating past productivity and changes therein on the basis of OM-based proxies. In contrast, the $\mathrm{Ba}$-containing mineral barite $\left(\mathrm{BaSO}_{4}\right)$ is well 
preserved in such depositional environments and may thus serve as a valuable tool to reconstruct changes in the influx of OM in sediments where OM-based productivity proxies often seem to fail. A close link between the marine geochemistry of barium and biological activity in the ocean has been documented for a variety of water column, sediment trap and sediment studies (Goldberg and Arrhenius, 1958; Chow and Goldberg, 1960; Dehairs et al., 1980; Collier and Edmond, 1984; Bishop, 1988; Dymond et al., 1992).The sedimentary Ba content, or more precisely the accumulation rate of socalled biogenic $\mathrm{Ba}$ has been proposed as a proxy for modern and past productivity (Bishop, 1988; Dehairs et al., 1991; Dymond et al., 1992). Discrete micron-sized barite $\left(\mathrm{BaSO}_{4}\right)$ crystals are the major carriers of non-detrital particulate barium in the water column (Dehairs et al., 1980; Bishop, 1988) and have been implicated as the particulate Ba phase directly related to marine carbon export flux (Dehairs et al., 1980; Dymond et al., 1992). Different terms are used in the literature to define this productivity-related fraction of Ba: "biogenic barium" (Babio), "excess Ba" (Baexcess) and "marine barite". Although the Ba proxy has been widely applied, and algorithms have been developed to reconstruct paleoproductivity from this inorganic geochemical tracer (e.g. Dymond et al., 1992; Gingele and Dahmke, 1994; Van Os et al., 1994; Francois et al., 1995; Schneider et al., 1997; Nürnberg et al., 1997; Pfeifer et al., 2001; Moreno et al., 2002; Hillenbrand et al., 2003; Weldeab et al., 2003a; 2003b; Meier et al., 2004; Reitz et al., 2004), fundamental questions remain concerning the exact mechanism/s of barite formation in the water column and its quantitative relationship to primary production and preservation.

Any possible mechanism for barite formation in the water column has to cope with the undersaturation of seawater with respect to barite (Monnin et al., 1999) and therefore requires either abiotic precipitation within supersaturated microenvironments or direct biologic mediation. Barite generation within bariumsulfate-saturated sub-oxic microenvironments of decaying biogenic debris is generally accepted to be the most likely barite-forming pathway (Bishop, 1988). Supersaturation with respect to barite within settling particles and aggregates may either be the result of sulfate regeneration from oxidation of sulphite or of organic-based sulfur compounds or from dissolution of celestite $\left(\mathrm{SrSO}_{4}\right)$ produced by Acantharia and siliceous Radiolaria which leads to a release of both sulfate and barium (Bernstein et al., 1992). In addition, active intracellular formation of barite is observed in benthic xenophyophores (Tendal, 1972; Gooday and Nott, 1982). However, due to the fragile nature of these large bottom-dwelling protozoans and the arising difficulties in sampling and identifying them, their role in the marine barite budget is still not understood.

If barite formation in the water column occurs proportionally to OM decomposition in aggregate microenvironments, its link to biological productivity is rather direct. If, however, barite precipitation is primarily coupled to a specific organism, the relationship between biological productivity and barium accumulation in sediments is more complex and quantitative estimates of paleoproductivity from sedimentary $\mathrm{Ba}$ contents are questionable. An experimental investigation of barite formation in seawater by Ganeshram et al. (2003) showed that living plankton represents a relatively large pool of labile $\mathrm{Ba}$, which is rapidly released during plankton decomposition and acts as the main source of $\mathrm{Ba}$ for barite formation in supersaturated microenvironments. The authors further concluded that the availability of microenvironments seems to be the limiting factor in barite precipitation. Although the "microenvironment mechanism" was conclusively shown to be the dominant barite forming pathway in the experiments performed by Ganeshram et al. (2003), several other studies emphasize that $\mathrm{Ba}$ input into the sediment in relation with particular organisms - like acantharians - can also be of relevance in specific ocean areas and/or under particular oceanographic/hydrographic conditions (Bernstein et al., 1992; Bertram and Cowen, 1994).

Despite the uncertainties that still exist with respect to the processes and mechanisms forming biogenic barite, sedimentary barium has proven to be a valuable indicator to trace the initial influx of OM, in certain environments as indicated below. Clear examples illustrating the value of barium as such an indicator have been given for the Eastern Mediterranean (Fig. 10; e.g. van Santvoort et al., 1996; Thomson et al., 1999; de Lange et al., 2008). Here, the upper part of an organic-rich unit has been oxidised postdepositionally removing the greater part of the OM fraction, but not affecting the biogenic barium content. For these case studies it appears that although most of the OM has been removed by a postdepositional downward progressing oxidation front, the initial signal is nicely reflected by the barite content that seems to have remained unaltered since accumulation. This has in part permitted the reconstruction not only of the most recent sapropel, but also of some of the entirely degraded older units (e.g. Thomson et al., 1995, 1999; van Santvoort et al., 1996, 1997). It must be noted here that for the extremely organic-rich (6-30\% organic carbon) sapropel units, mobilization of barite has occurred in line with the demonstrated bottom water anoxia during such periods (e.g. Passier et al., 1999). In the latter case, organic carbon preservation is usually enhanced so organic carbon itself is a good indicator of initial organic fluxes. It seems therefore that barite can serve as a useful proxy for moderate initial organic carbon fluxes, in particular since such moderate organic carbon contents often leads to its partial or even total degradation. Similar downward oxidation processes have occurred in the Madeira Abyssal Plain organic-rich units that are of turbidite origin.

It turns out that such oxidation fronts were also active during major glacial/interglacial transitions. A study in the oligotrophic and low sedimentation regimes of the Equatorial Atlantic Ocean revealed distinct peaks of excess Ba at glacial terminations unrelated to any other productivity proxy 

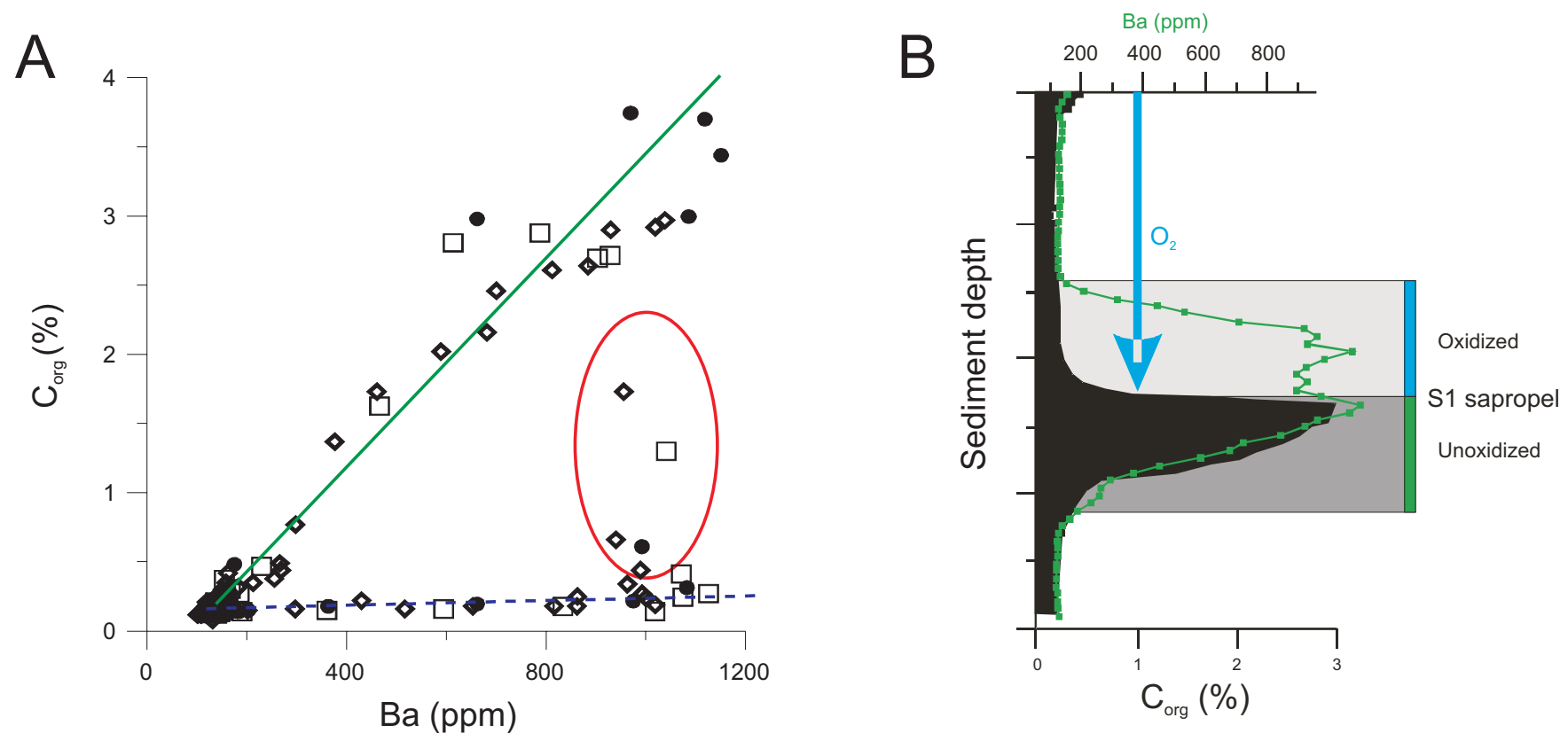

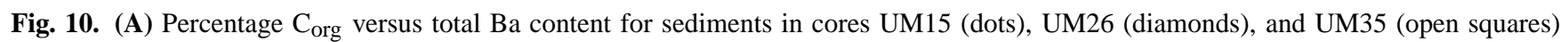
(modified from van Santvoort et al., 1996). The green line indicates the trend for un-oxidized samples, the blue dashed line those for oxidized samples, whereas the red oval indicates partly oxidized samples. (B) total $\mathrm{Ba}$ and $\mathrm{C}_{\text {org }}$ in eastern Mediterranean sediment (modified from de Lange et al., 2008), illustrating the progression of the oxidation front (= removal of $\mathrm{C}_{\text {org }}$ while maintaining Ba content).

(Kasten et al., 2001). Similar Ba spikes at climate transitions not supported by other productivity tracers have also been reported from other locations in the Atlantic and Pacific but have remained unexplained so far (Matthewson et al., 1995; Schwarz et al., 1996). Kasten et al. (2001) could demonstrate that these $\mathrm{Ba}$ maxima indeed represent productivity pulses, and that the discrepancy between barium and TOC in the transitional sediment intervals (Fig. 11) was caused by complete post-depositional degradation of non-refractory TOC due to the action of downward-progressing oxidation fronts during deglacial nonsteady-state conditions. This hypothesis was further corroborated by a study of Moreno et al. (2002) in the North Canary Basin off Cape Ghir, where large productivity events were detected at Terminations I, II and III by a multi-productivity-proxy approach. In their core GeoB 4216 which was characterized by mean sedimentation rates of $4.9 \mathrm{~cm} / \mathrm{kyr}$ coinciding peaks of $\mathrm{Ba}$ and TOC were found. In contrast, at site GeoB 5559 located further offshore and subject to significantly lower sedimentation rates of about $2.4 \mathrm{~cm} / \mathrm{kyr}$ similar Ba spikes at Terminations were not supported by TOC enrichments.

A supplementary high-resolution analysis performed along the last and the penultimate glacial/interglacial transition in core GeoB 4216 (Fig. 11) from the North Canary Basin serves as a further valuable example supporting the suitability of $\mathrm{Ba}$ as a productivity tracer in this area (Kasten et al., 2003). The perfect match between $\mathrm{Ba}(\mathrm{Ba} / \mathrm{Ti}$ ratios) and TOC in the lower, unoxidized part of the Ba-enriched sediment intervals (Fig. 11) suggests that the input of $\mathrm{Ba}_{\text {bio }}$ or
$\mathrm{Ba}_{\text {excess }}$ must have occurred proportional to the input flux of $\mathrm{TOC}$ and that the $\mathrm{TOC} / \mathrm{Ba}_{\text {bio }}$ ratio of the particulate material reaching the seafloor must have been more or less constant over time. This close correlation between $\mathrm{Ba}$ and TOC as well as the distribution of Ba displaying a broad peak further implies that the Ba profiles indeed trace periods of elevated productivity and do not stem from authigenic barite formation.

The different degrees of post-depositional TOC oxidation along the glacial/interglacial transitions as shown in the two examples above are controlled by the overall rate of sedimentation as well as the magnitude of change in environmental and depositional conditions that occurred during these full climatic transitions. Using a modelling approach, Jung et al. (1997) demonstrated that sedimentation rate is the dominant factor which controls whether a sapropel is oxidized completely or only partly (also cf. Higgs et al., 1994; van Santvoort et al., 1997). Jung et al. (1997) showed that preservation of elevated concentrations of non-refractory organic carbon is generally improbable when the sedimentation rate is lower than $1-2 \mathrm{~cm} / \mathrm{kyr}$. This value corresponds well to the value of about 2 to $2.5 \mathrm{~cm} / \mathrm{kyr}$ on average for the Ceará Rise site where no correlation between $\mathrm{Ba}$ and TOC at glacial/interglacial transitions has been found (Fig. 11). At station GeoB 4216, which is characterized by slightly higher sedimentation rates, only the upper part of the TOCenriched interval has been affected by post-depositional oxidation (Fig. 11). 


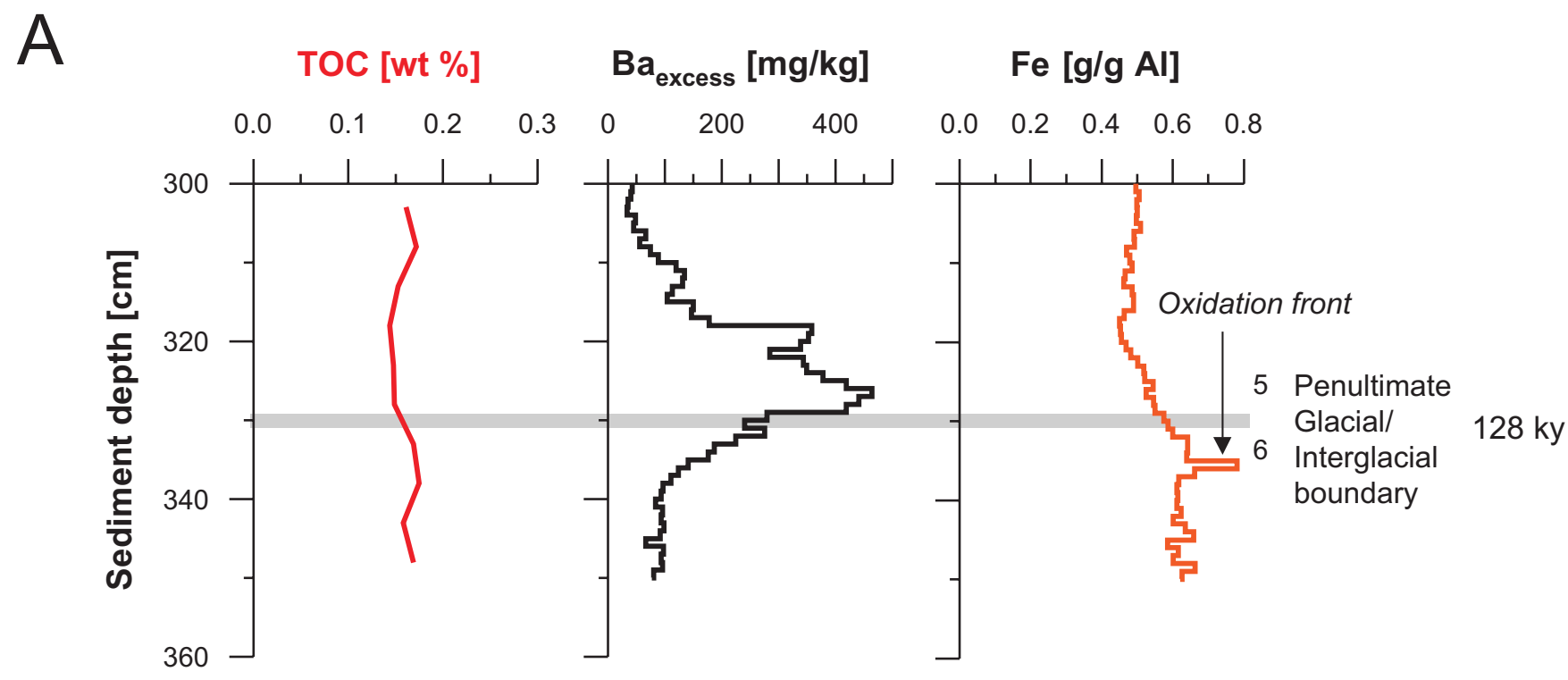

B

TOC [wt\%]

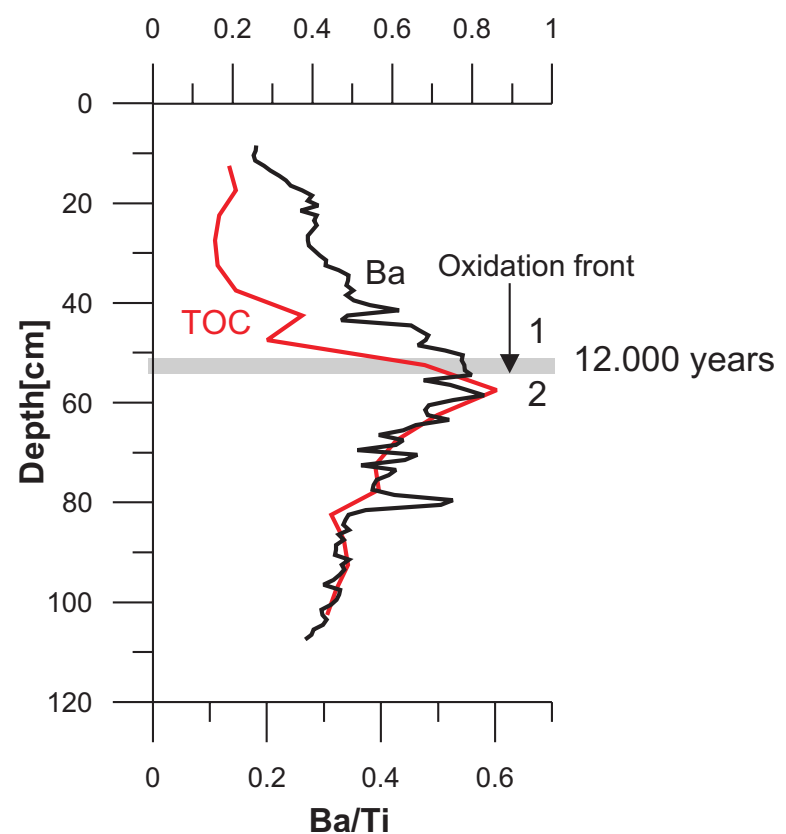

TOC [wt\%]

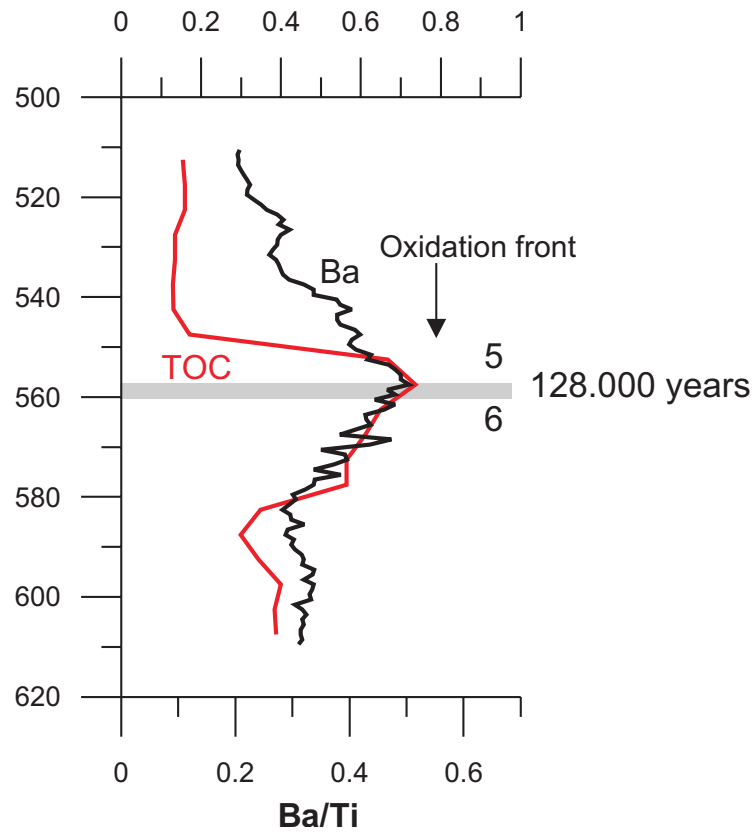

Fig. 11. (A) Complete post-depositional oxidation of non-refractory TOC across the penultimate glacial/interglacial transition (oxygen isotope stage boundary 6/5) in sediments of site GeoB 1523 on the Céara Rise (modified from Kasten et al., 2001). The initially present TOC has been degraded - leaving solid-phase $\mathrm{Ba}$ as a relict. The distribution of Fe with a distinct peak below the glacial/interglacial boundary marks the depth to which the oxidation front progressed down and then remained fixed for a considerable time before moving up again adapting to the new geochemical conditions. (B) Action of oxidation fronts across full glacial/interglacial boundaries in sediments of the Canary Island region (core GeoB 4216). While the $\mathrm{Ba} / \mathrm{Ti}$ and TOC profiles perfectly match in the lower part of the Ba peaks, a discrepancy between these two parameters is found in the upper part which points to a partial post-depositional TOC oxidation (modified from Kasten et al., 2003). While TOC is selectively degraded during re-oxidation of the previously sub-oxic sediment Ba is not affected by this aerobic decay of organic matter or oxidation of possible pre-formed sulfides and can thus serve as valuable indicator of the initial productivity pulses at this site. 
The utility of biogenic or excess barium as a productivity tracer is definitely restricted in (1) continental margin settings subject to high input of either eolian or riverine terrigenous matter or strong lateral material transport (e.g. Dymond et al., 1992; Reitz et al., 2004 and references therein), and in (2) ocean areas characterized by high-productivity conditions in surface waters (Gingele et al., 1999 and references therein). In particular, the latter sites underlying euphotic surface waters, provide a nice example of how OM breakdown modifies other proxies. These sites mostly have high rates of sedimentary methane production and a shallow (only a few meters below the sediment surface) location of the socalled sulfate/methane transition (SMT) where the anaerobic oxidation of methane with sulfate occurs. Along this geochemical reaction zone the strongest diagenetic redistribution of barite takes place with barite crystals being dissolved when buried into the sulfate-depleted sediments below the SMT and reprecipitation of authigenic/diagenetic barite slightly above the SMT in so-called barite fronts (e.g. Torres et al., 1996; Gingele et al., 1999; Riedinger et al., 2006).

However, as has been shown above, in spite of these limitations, sedimentary Ba can serve as a valuable productivity proxy in overall low productivity and low sedimentation ocean areas where it seems to have considerable advantage over other productivity tracers. Compared to biogenic sediment components like TOC, opal, carbonate or specific molecular organic compounds/biomarkers which are subject to strong and variable degrees of decomposition and/or dissolution - both on their way through the water column and after deposition on the seafloor - barite has the advantage that as much as about $30 \%$ of the primary flux from the photic zone may be preserved within the sediment (Dymond et al., 1992). Thus, the barium proxy might be a robust supplement for productivity reconstructions from organic or biogenic sediment compounds in that it comes into play in more remote, low sedimentation and well oxygenated depositional environments where organic compounds most severely suffer from diagenetic overprint. Furthermore, the barium proxy may provide an effective way to identify and semi-quantify impact on OM degradation in such settings.

\subsection{Influences of diagenesis on $\delta^{15} \mathrm{~N}$ composition of bulk sediment as viewed through amino acid preservation}

The amino acid composition of sediment samples shows systematic changes upon progressive degradation. This behaviour has been used to derive a quantitative degradation index which allows quantifying the quality of OM based solely on its chemical composition (Vandewiele et al., 2009; Dauwe et al., 1999). At the same time, amino acids are the main carriers of nitrogen in OM. Stable isotope ratios of nitrogen are an established proxy in reconstructions of nutrient regimes and global productivity patterns from sediments. They have been used to elucidate changes in nitrogen cycling (denitrification, $\mathrm{N}_{2}$-fixation) and nutrient utilisation in the global ocean (Ganeshram et al., 2002; Deutsch et al., 2004; Altabet, 2007) and individual ocean basins (Farrell et al., 1995; Haug et al., 1998; Ganeshram et al., 2000) over a large range of geological scales (Haug et al., 1998; Struck et al., 2000; Jenkyns et al., 2001; Altabet et al., 2002). Howerver, the extent to which protein/amino acid degradation affects the nitrogen stable isotope composition $\left(\delta^{15} \mathrm{~N}\right)$ of sediments remains a matter of ongoing debate.

Mineralization processes apparently result in enrichment in ${ }^{15} \mathrm{~N}$ for particles sinking from the euphotic zone and transitting to the sea floor through oxic water columns (Altabet and Francois, 1994; Lehmann et al., 2002; Gaye-Haake et al., 2005). Offsets in $\delta^{15} \mathrm{~N}$ by 3-5\%obetween particles in the water column and surface sediments have been observed in open ocean sediments (Francois et al., 1992; Francois et al., 1997; Altabet et al., 1999). In contrast, ${ }^{15} \mathrm{~N}$ depletion in particulate organic nitrogen (PON) occurs during diagenesis under oxygen-deficient conditions (Wada et al., 1980; Libes and Deuser, 1988; Lehmann et al., 2002). This is thought to either reflect an increase in bacterial biomass that assimilated isotopically depleted dissolved inorganic nitrogen (DIN), dissolved organic nitrogen (DON), or ammonia, or to reflect inefficient protein degradation due to lack of molecular oxygen at the sediment-water interface. After deposition, preservation of proteins may be aided by rapid sedimentation that efficiently isolates relatively pristine OM away from oxygenated bottom waters; similarly, an influence of rapid transfer through the water column by mineral ballasting is indicated by lower $\delta^{15} \mathrm{~N}$ ratios in sediments with input of eolian dust (Holmes et al., 2003)

To evaluate possible influences of diagenesis on sediment $\delta^{15} \mathrm{~N}$, Möbius et al. (2010) determined amino acid composition and the stable nitrogen isotopic compositions of bulk sediment in sediment cores from the Arabian Sea that bracket large differences in sedimentation rates and oxygenation of the sea floor. All records show a positive correlation of $\delta^{15} \mathrm{~N}$ and the reactivity of amino acids and indicate that better preserved $\mathrm{OM}$ is enriched in ${ }^{15} \mathrm{~N}$ in the Arabian Sea, consistent with observations by Gaye-Haake et al. (2005). The data thus confirm that changes in the isotopic source signal of nitrate, commonly attributed to variations in the intensity of denitrification in the regional mid-water oxygen minimum zone (OMZ), covary with enhanced OM preservation. Different accumulation rates of the cores apparently have minor effect on either amino acid reactivity or $\delta^{15} \mathrm{~N}$. The basin-wide comparison of $\delta^{15} \mathrm{Ng}$ records shows similar and coeval patterns through time over the last $130 \mathrm{kyr}$, but different average values of $\delta^{15} \mathrm{~N}$ at each core location. $\delta^{15} \mathrm{~N}$ mean values are positively correlated with water depth and point to more intense degradation in thicker oxic water columns over each site (Gaye-Haake et al., 2005). Hence, relative $\delta^{15} \mathrm{~N}$ patterns in core records do reflect the isotopic composition of source nitrate; however, absolute values are altered during 
early degradation. Thus $\delta^{15} \mathrm{~N}$ records in the Arabian Sea and elsewhere apparently are reliable proxies for the regional nitrogen cycle on geological time scales, but the records are affected by different diagenetic offsets, making reconstructions of gradients in nitrate availability and nitrate utilisation even in one basin difficult. Compound specific $\delta^{15} \mathrm{~N}$ analyses on chlorophyll (Sachs and Repeta, 1999) or Nitrogen in diatom frustules (Brunelle et al., 2007) may provide ways to avoid diagenetic effects.

\subsection{The use of selective preservation of organic-walled dinoflagellate cysts to separate the palaeoproductivity from the preservation signals}

To date, most proxies used to estimate past marine primary production are based on the chemical and molecular composition as well as on the total amount of OM preserved in marine sediments. However, as discussed in the previous chapters, one of the most important factors determining the rate in which these processes alter the initial signal is the availability of oxygen in bottom/pore waters as well as the dissolved oxygen concentrations. Estimation of bottom/pore water oxygen concentrations therefore forms a key question in determining the extent of selective OM degradation. Recently, a method to reconstruct bottom water oxygen concentrations has been proposed. This method exploits the vastly different degradation rates that organic components from the same source can exhibit in oxic environments (Versteegh and Zonneveld, 2002; Zonneveld et al., 2007). Organic walled dinoflagellate cysts fulfil these conditions and they appear to be extremely suitable application of the method. Culturing experiments indicate that these cysts are produced in the upper part of the water column and that cyst production increases when nutrient, trace element or food availability is enhanced (e.g. Pfiester and Anderson, 1987; Ishikawa and Taniguchi, 1996; Montresor et al., 1998; Kremp and Heiskanen, 1999; Godhe et al., 2001). Studies on material intercepted by sediment traps located at different depths at one mooring site indicate that cysts produced in the upper water column are rapidly transported to the sea floor (probably within faecal pellets and plankton aggregates) without any detectable species-selective degradation in the water column has not been observed (Zonneveld et al., 2010; Susek et al., 2005). In addition, no evidence has been found for speciesselective lateral transport within the nepheloid layer or in the water column (e.g. Marret and Zonneveld, 2003).

By studying the post-depositional aerobic OM degradation at natural oxidation fronts in Late Quaternary sediments of the Madeira Abyssal Plain f-turbidite (140 ka BP), the midHolocene Eastern Mediterranean Sapropel S1, and the modern Arabian Sea Oxygen Minimum Zone and surrounding sediments, Versteegh and Zonneveld (2002) discovered that the organic-walled cysts of some species are extremely resistant to aerobic degradation. Their refractory nature was confirmed in short-term degradation experiments in natural

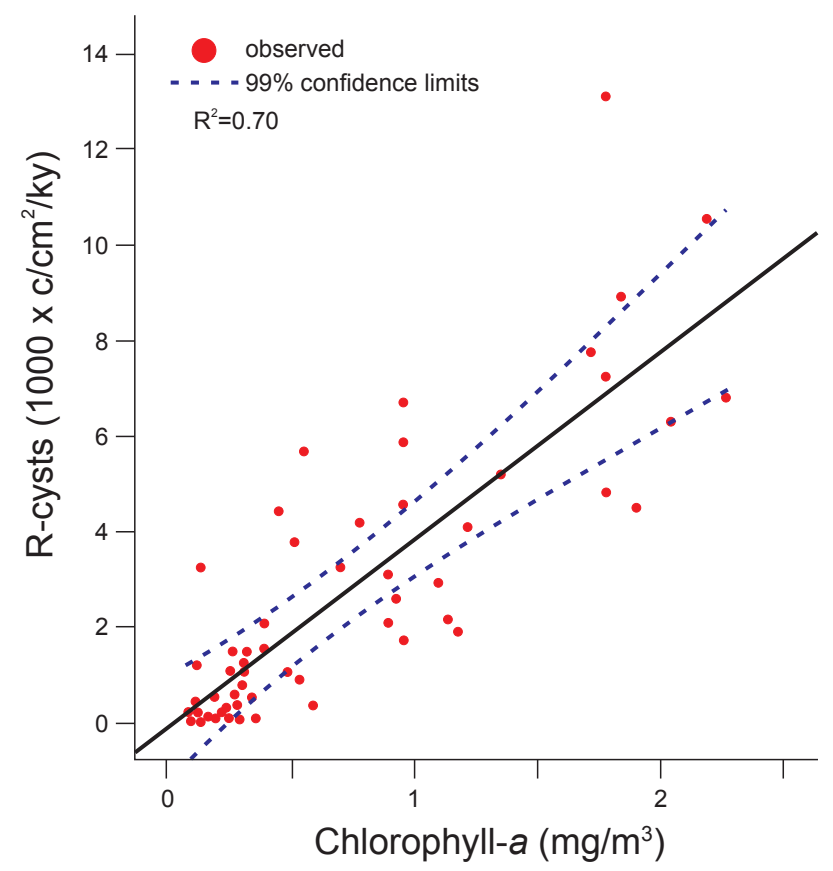

Fig. 12. Relationship between accumulation rates of resistant cysts (R-cysts) and mean annual upper water chlorophyll- $a$ concentrations. Estimated linear relationship with $99.9 \%$ confidence limits of mean (modified from Zonneveld et al., 2007).

environments where no short-term degradation can be observed (Kodranz-Nsiah et al., 2008). Recently it has been shown that accumulation rates of this group of cysts in modern sediments are linearly related to upper ocean chlorophyll$a$ concentrations as measured by satellite imaging (Fig. 12) (Zonneveld et al., 2007). In older sediments, accumulation rates of the group of resistant cyst species can strongly be correlated to other productivity proxies such as the $\mathrm{Ba} / \mathrm{Al}$ ratio (Bockelmann, 2007). By grouping resistant cysts with different ecologies the effects on the cyst production of other environmental factors such as sea surface temperature, salinity and individual nutrient or trace element concentrations on the cyst production can be filtered out. So far the only exception observed is in areas of strong turbulence in the upper water column such as active upwelling cells, probably because strong turbulence inhibits growth of all dinoflagellates (Ross and Sharples, 2007). Consequently, with the exception of areas influenced by active upwelling, accumulation rates of dinoflagellates resistant to aerobic degradation form a high quality quantitative proxy for net primary productivity.

In contrast to resistant cysts, laboratory experiments and degradation experiments in natural environments have shown that another group of organic-walled dinoflagellate cysts is extremely vulnerable to degradation in oxic environments compared to other OM components (e.g. Marret, 1993; Zonneveld et al., 1997; Versteegh and Zonneveld, 2002; Hopkins and McCarthy, 2002; Mudie and McCarthy, 2006). There is 


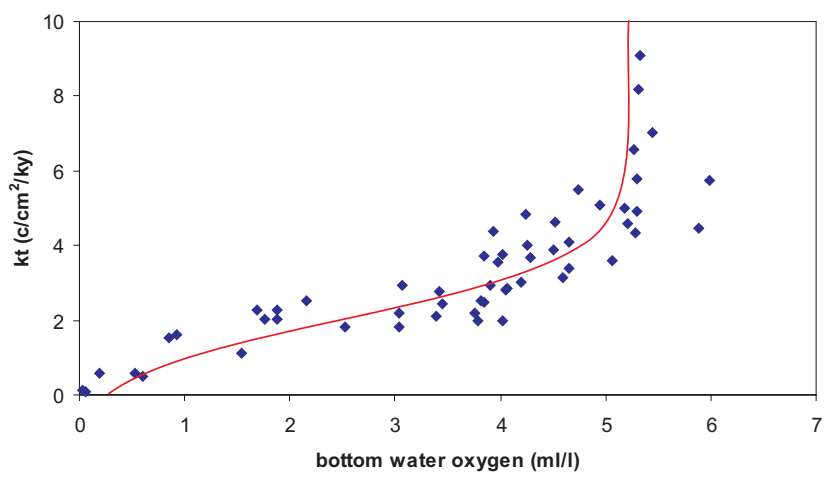

Fig. 13. Relationship between the degradation S-cysts expressed as $k t$ and bottom water oxygen concentration $\left(\mathrm{O}_{2}\right)$. $k=$ degradation constant; $t=$ time (ky), whereby a first-order decay is assumed, $k t=\ln \left(\mathrm{X}_{i} / \mathrm{X}_{f}\right)$ with $\mathrm{X}_{f}=$ final cyst concentration (cysts $\mathrm{cm}^{-2} \mathrm{ky}^{-1}$ ) and $\mathrm{X}_{i}=$ initial cyst concentration (cysts $\mathrm{cm}^{-2} \mathrm{ky}^{-1}$ ) (modified from Zonneveld et al., 2007).

a strong indication that differential degradation results from different molecular structures of the cysts (Zonneveld et al., 2008). Numerous studies on the geographic distribution of dinoflagellate cysts indicate that a mixture of members of both groups of species can be found in all marine sediments (e.g. Marret and Zonneveld, 2003). Sediment trap studies and studies in regions where OM in surface sediments is not altered by aerobic degradation suggest that the production rates of both groups are linearly related (Zonneveld et al., in press; Zonneveld et al., 2007). The degradation of the sensitive cysts is logarithmic, however, so that the primary production signal of the latter is often diagenetically overprinted. By assuming a linear relationship between the cyst production of both groups and a logarithmic degradation of vulnerable cysts in aerobic environments, a degradation index can be established. The value of this degradation index calculated from cyst accumulation rates in modern surface sediments shows a strong correlation with bottom water oxygen concentrations (Fig. 13) and might thus form a useful tool to reconstruct past bottom water oxygen concentration and deep ocean ventilation.

The relationship between the cyst degradation index and oxygen concentration in bottom waters is highly non-linear (Fig. 13), with degradation virtually absent under anoxic conditions, slowly increasing degradation rates up to an oxygen concentration of $4 \mathrm{ml} / \mathrm{l}$, and a shift to very high degradation rates above this $\mathrm{O}_{2}$ concentration. This non-linear pattern can be explained assuming that oxygen concentrations are the limiting factor controlling the growth rate the cystdegrading organisms under low-oxygen conditions (Jorge and Livingston, 1999; Guerra-Garcia and García-Gómez, 2005). At intermediate oxygen concentrations the population size of the degrader increases with a constant rate up to a certain threshold oxygen concentration, above which the heterotrophic population will consume all sensitive cysts, leading the degradation index values to increase to infinity.
With the exception of only a few species, the molecular structure of organic dinoflagellate cysts is poorly known (Hemsley et al., 1994; Kokinos et al., 1998; Versteegh and Blokker, 2004; Versteegh et al., 2007). Nevertheless, some of the previously desctibed OM modification processes, including sulphurisation or oxidative polymerisation of the original cyst wall biomolecule, may be important in its preservation (Versteegh et al., 2007). Although degradation rates and mechanisms for individual cyst species are not well known, the large differences in degradation and transformation of cysts from different dinoflagellate taxa may function as a model for the degradation of kerogen in general, but with the major advantage that (in contrast to most other kerogen) the cysts can be related reliably to their source organism, and thus the original biomolecule, at a low taxonomical level. This may allow examination of kerogen transformation under tightly constrained biological and biochemical conditions on geological time scales. Thus, the use of differential degradation of dinoflagellate cysts may not only be useful for reconstructing past export production and diagenetic overprinting, but the method may be applicable to a wide array of organic components with a common source.

\section{Conclusions}

There remains much debate about the different controls on OM preservation in marine sediments, although it appears that most of the factors influencing OM preservation have been identified (Fig. 3). Furthermore, precisely how some of these factors influence preservation is not yet fully understood. The mechanisms by which many factors operate are partly or even fragmentarily understood, such as the role of oxygen on preservation or the roles of polymerisation reactions in enhancing OM preservation. Other factors, such as the influence of pressure or mineralogical composition of the sediments, have not even taken carefully into consideration. This incomplete understanding of OM breakdown hampers proper assessment of the present carbon cycle, and to an even larger extent that operating in the past.

Our limited understanding of the behaviour of sedimentary $\mathrm{OM}$ also hampers the interpretation of $\mathrm{OM}$ based proxies (such as the $\mathrm{U}_{37}^{K^{\prime}}, \mathrm{TEX}_{86}$ and BIT indices) and other proxies which are modified by processes resulting from OM breakdown (such as biogenic barium). The translation of a given proxy to its environment of formation (transfer function) should thus be expanded by a "deformation function" taking into account the transport and diagenesis-related molecular and atomic modifications to these signals that took place during the period between proxy formation and analysis. Although our knowledge of the factors influencing OM production and preservation remains fragmentary, some promising proxies for $\mathrm{OM}$ degradation are emerging that may shed light on this deformation function. Specifically, use of palynomorph concentrations and selective changes 
in assemblage composition as models for production and preservation of OM, may lead to correction for biases due to selective degradation. This type of quantitative assessment of OM degradation would ultimately enable more accurate reconstruction of past productivity and bottom water oxygenation. Overall, given the cost and effort associated with field programs to recover sediment cores for paleoclimatological studies, as well as with generating well the proxy records, it would seem wise to develop a detailed sedimentological and diagenetic context for interpretation of these records. With respect to the latter, parallel acquisition of data that would inform on the fidelity of the proxy signatures and reveal potential diagenetic biases would be of clear value.

Acknowledgements. We thank Stefan Schouten for useful comments on an earlier version of the manuscript. We acknowledge generous financial support by the DFG Research Center/Cluster of Excellence MARUM "The Ocean in the Earth System", the International Graduate College EUROPROX and the Alfred Wegener Institute for Polar and Marine Research enabling the realisation of the "Workshop on Selective Preservation of Organic Matter: Processes and Impact on the Fossil Record" which formed the basis of this paper. GJMV acknowledges support by the German Science Foundation (DFG grant VE486/2).

Edited by: S. Pantoja

\section{References}

Aller, R. C.: Transport and reactions in the bioirrigated zone, in: The Benthic Boundary Layer, edited by: Boudreau, B. P. and Jørgensen, B. B., Oxford University Press, Oxford, 269-301, 2001.

Aller, R. C. and Blair, N. E.: Carbon remineralization in the Amazon-Guianas tropical mobile mudbelt: A sedimentary incinerator, Cont. Shelf Res., 26(17-18), 2241-2259, 2006.

Altabet, M. A.: Constraints on oceanic $\mathrm{N}$ balance/imbalance from sedimentary ${ }^{15} \mathrm{~N}$ records, Biogeosciences, 4, 75-86, 2007 , http://www.biogeosciences.net/4/75/2007/.

Altabet, M. A. and Francois, R.: The use of nitrogen isotopic ratio for reconstruction of past changes in surface ocean nutrient utilization, in: Carbon Cycling in the Glacial Ocean: Constraints on the Ocean's Role in Global Change, edited by: Zahn, R., Pedersen, T. F., Kaminski, M. A., and Labeyrie, L., Springer, Berlin, 281-306, 1994.

Altabet, M. A., Higginson, M. J. and Murrey, D. W.: The effect of millennial-scale changes in Arabian Sea denitrification on atmospheric $\mathrm{CO}_{2}$, Nature, 415, 159-162, 2002.

Arnarson, T. S. and Keil, R. G.: Organic-mineral interactions in marine sediments studied using density fractionation and X-ray photoelectron spectroscopy, Org. Geochem. 32, 1401-1415, 2001.

Arnarson, T. S. and Keil, R. G.: Influence of organic-mineral aggregates on microbial degradation of the dinoflagellate Scrippsiella trochoidea, Geochim. Cosmochim. Ac., 69(8), 2111-2117, 2005.
Arnarson, T. S. and Keil, R. G.: Changes in organic matter-mineral interactions for marine sediments with varying oxygen exposure times, Geochim. Cosmochim. Ac., 71, 3545-3556, 2007.

Armstrong, R. A., Peterson, M. L., Lee, C., and Wakeham, S. G.: Settling velocity spectra and the ballast ratio hypothesis, Deep Sea Res. Pt. II, 56, 1470-1478, 2009.

Arnosti, C., Ziervogel, K., Ocampo, L., and Ghobrial, S.: Enzyme activities in the water column and in shallow permeable sediments from the northeastern Gulf of Mexico, Estuar. Coast. Shelf S., 84, 202-208, 2009.

Bahri, H., Dignac, M. F., Rumpel, C., Rasse, D. P., Chenu, C., and Mariotti, A.: Lignin turnover kinetics in an agricultural soil is monomer specific, Soil Biol. Biochem., 38(7), 1977-1988, 2006.

Bastviken, D., Persson, L., Odham, G., and Tranvik, L.: Degradation of dissolved organic matter in oxic and anoxic lake water, Limnol. Oceanogr., 49, 109-116, 2004.

Bauer, J. E., Williams, P. M., and Druffel, E. R. M.: ${ }^{14} \mathrm{C}$ activity of dissolved organic carbon fractions in the north-central Pacific and Sargossa Sea, Nature, 357, 667-670, 1992.

Bernstein, R. E., Byrne, R. H., Betzer, P. R., and Greco, A. M.: Morphologies and transformations of celestite in seawater: The role of acantharians in strontium and barium geochemistry, Geochim. Cosmochim. Ac., 56(8), 3273-3279, 1992.

Bertram, M. A. and Cowen, J. P.: The form, composition and origin of marine barite, Eos, 75, 382, 1994.

Bianchi, T. S., Wysocki, L. A., Stewart, M., Filley, T. R., and McKee, B. A.: Temporal variability in terrestrially-derived sources of particulate organic carbon in the lower Mississippi River and its upper tributaries, Geochim. Cosmochim. Ac., 71(18), 44253744, 2007.

Bishop, J. K. B.: The barite-opal-organic carbon association in oceanic particulate matter, Nature, 332, 341-343, 1988.

Blom, A. V.: Quelques remarques sur le mécanisme de séchage des peintures à l'huile, Peintures, Pigments, Vernis, 13, 156-162, 1936.

Bockelmann, F.-D.: Selective preservation of organic-walled dinoflagellate cysts in Quaternary marine sediments: An oxygen effect and its application to paleoceanography, Ph.D., Bremen University, 1-130, 2007.

Brassell, S. C., Eglinton, G., Marlowe I. T., Pflaumann U., and Sarnthein, M.: Molecular stratigraphy: a new tool for climatic assessment, Nature, 320, 129-133, 1986.

Brunelle, B. G., Sigman, D. M., Cook, M. S., Keigwin, L. D., Haug, G. H., Plessen, B., Schettler, G., and Jaccard, S. L.: Evidence from diatom-bound nitrogen isotopes for subarctic Pacific stratification during the last ice age and a link to North Pacific denitrification changes, Paleoceanogr., 22, 1-17, 2007.

Burdige, D. J.: Burial of terrestrial organic matter in marine sediments: A re-assessment, Glob. Biogeochem. Cy., 19(4), GB4011, doi:10.1029/2004GB002368, 2005.

Cacho, I., Grimalt, J. O., Sierro, F. J., Shackleton, N. J., and Canals, M.: Evidence for enhanced Mediterranean thermohaline circulation during rapid climatic coolings, Earth Planet. Sci. Lett., 183(3-4), 417-429, 2000.

Canfield, D. E.: Factors influencing organic carbon preservation in marine sediments, Chem. Geol., 114, 315-329, 1994.

Canfield, D. E. and Thamdrup, B.: Towards a consistent classification scheme for geochemical environments, or, why we wish the term "suboxic" would go away, Geobiol, 7, 385-392, 2009. 
Chow, T. J. and Goldberg, E. D.: On the marine geochemistry of barium, Geochim. Cosmochim. Ac., 20(3-4), 192-198, 1960.

Cooke, M. P., Talbot, H. M., and Farrimond, P.: Bacterial populations recorded in bacteriohopanepolyol distributions in soils from Northern England, Org. Geochem., 39, 1347-1358, 2008.

Coppola, L., Gustafsson, O., Andersson, R., Eglinton, T. I., Uchida, M., and Dickens, A. F.: The importance of ultrafine particles as a control on the distribution of organic carbon in Washington Margin and Cascadia Basin sediments, Chem. Geol., 243(1-2), 142-156, 2007.

Collier, R. and Edmond, J.: The trace element geochemistry of marine biogenic particulate matter, Progr. Oceanogr., 13(2), 113199, 1984.

Czimczik, C. I. and Masiello, C. A.: Controls on black carbon storage in soils, Glob. Biogeochem. Cy., 21, GB3005, doi:10.1029/2006GB002798, 2007.

Dauwe, B., Middelburg, J. J., Herman, P. M. J., and Heip, C. H. R.: Linking diagenetic alteration of amini acids and bulk organic matter reactivity, Limnol. Oceanogr., 44(7), 1809-1814, 1999.

de Lange, G. J., Thomson, J., Reitz, A., Slomp, C. P., Principato, M. S., Erba, E., and Corselli, C.: Synchronous basin-wide formation and redox-controlled preservation of a Mediterranean sapropel, Nat. Geosci., 1, 606-610, 2008.

de Leeuw, J. W.: On the origin of sedimentary aliphatic macromolecules: A comment on recent publications by Gupta et al., Org. Geochem., 38(9), 1585-1587, 2007.

de Leeuw, J. W., Versteegh, G. J. M., and van Bergen, P. F.: Biomacromolecules of plants and algae and their fossil analogues, Plant. Ecol., 189, 209-233, doi:10.1007/s11258-0059027-x, 2006.

De Vargas, C., Aubry, M.-P., Probert, I., and Young, J.: Origin and evolution of Coccolithophores: from coastal hunters to oceanic farmers, in: Evolution of Primary Producers in the Sea, edited by: Falkowski, P. G. and Knoll, A., Academic Press, London, 251-285, 2007.

Dehairs, F., Chesselet R., and Jedwab, J.: Discrete suspended particles of barite and the barium cycle in the open ocean, Earth Planet. Sci. Lett., 49(2), 528-550, 1980.

Dehairs, F., Stroobants, N., and Goeyens, L.: Barite formation in the southern-ocean water column, Mar. Chem., 35(1-4), 399410, 1991.

Deutsch, C., Sigman, D. M., Thunell, R. C., Meckler, A. N., and Haug, G. H.: Isotopic constraints on glacial/interglacial changes in the oceanic nitrogen budget, Glob. Biogeochem. Cy., 18, GB4012, doi:10.1029/2003GB002189, 2004.

Dignac, M. F., Bahri, H., Rumpel, C., Rasse, D. P., Bardoux, G., Balesdent, J., Girardin, C., Chenu, C., and Mariotti, A.: Carbon13 natural abundance as a tool to study the dynamics of lignin monomers in soil: an appraisal at the Closeaux experimental field (France), Geoderma, 128(1-2), 3-17, 2005.

Dittmar, T. and Koch, B. P.: Thermogenic organic matter dissolved in the abyssal ocean, Mar. Chem., 102(3-4), 208-217, 2006.

Dorgan, K. M., Jumars, P. A., Johnson, B., Boudreau, B. P., and Landis, E.: Burrowing mechanics: Burrow extension by crack propagation, Nature, 433, 475, 2005.

Dymond, J., Suess, E., and Lyle, M.: Barium in deep-sea sediment: a geochemical indicator of paleoproductivity, Paleoceanogr., 7, 163-181, 1992.

Eglinton, T. I., Conte, M. H., Eglinton, G., and Hayes, J. M.: Pro- ceedings of a workshop on alkenone-based paleoceanographic indicators, Geochem. Geophys. Geosyst., 2, 2000GC000122, doi:10.1029/2000GC000122, 2001.

Farrell, J. W., Pedersen, T. F., Calvert, S. E., and Nielsen, B.: Glacial-interglacial changes in nutrient utilization in the equatorial Pacific Ocean, Nature, 377, 514-517, 1995.

Francois, R., Honjo, S., Manganini, S. J., and Ravizza, G. E.: Biogenic barium fluxes to the deep-sea: implications for paleoproductivity reconstruction, Glob. Biogeochem. Cy., 9(2), 289-301, 1995.

Froelich, P. N., Klinkhammer, G. P., Bender, M. L., Luedtke, N. A., Heath, G. R., Cullen, D., Dauphin, P., Hammond, D., Hartman, B., and Maynard, V.: Early oxidation of organic matter in pelagic sediments of the eastern equatorial Atlantic: suboxic diagenesis, Geochim. Cosmochim. Ac., 43, 1075-1090, 1979.

Ganeshram, R. S., François, R., Commeau, J., and Brown-Leger, S. L.: An experimental investigation of barite formation in seawater, Geochim. Cosmochim. Ac, 67(14), 2599-2605, 2003.

Ganeshram, R. S., Pedersen, T. F., Calvert, S. E., and François, R.: Reduced nitrogen fixation in the glacial ocean inferred from changes in marine nitrogen and phosphorus inventories, Nature, 415(6868), 156-159, 2002.

Ganeshram, R. S., Pedersen, T. F., Calvert, S. E., McNeill, G. W., and Fontugne, M. R.: Glacial-interglacial variability in denitrification in the world's oceans: causes and consequences, Paleoceanogr., 15(4), 361-376, 2000.

Gaye-Haake, B., Lahajnar, N., Emeis, K.-C., Unger, D., Rixen, T., Suthhof, A., Ramaswamy, V., Schulz, H., Paropkari, A. L., Guptha, M. V. S., and Ittekkot, V.: Stable nitrogen isotopic ratios of sinking particles and sediments from the northern Indian Ocean, Mar. Chem., 96(3-4), 243-255, 2005.

Gingele, F. and Dahmke, A.: Discrete barite particles and barium as tracers of paleoproductivety in South Atlantic sediments, Paleoceanogr., 9(1), 151-168, 1994.

Gingele, F. X., Zabel, M., Kasten, S., Bonn, W. J., and Nürnberg, C. C.: Biogenic barium as proxy for paleoproductivity: methods and limitations of application, in: Use of Proxies in Oceanography, edited by: Fischer, G. and Wefer, G., Springer, Berlin, 365-392, 1999.

Gleixner, G., Poirier, N., Bol, R., and Balesdent, J.: Molecular dynamics of organic matter in a cultivated soil, Org. Geochem., 33(3), 357-366, 2002.

Glud, R. N.: Oxygen dynamics of marine sediments, Mar. Biol. Res., 4(4), 243-289, 2008.

Godhe, A., Norén, F., Kulenstierna, M., Ekberg, C., and Karlson, B.: Relationship between planktonic dinoflagellate abundance, cysts recovered in sediment traps and environmental factors in the Gullmar Fjord, Sweden, J. Plankton Res., 23(9), 923-938, 2001.

Goldberg, E. D. and Arrhenius, G. O. S.: Chemistry of Pacific pelagic sediments, Geochim. Cosmochim. Ac., 13(2-3), 199212, 1958.

Gong, C. and Hollander D. J.: Evidence for differential degradation of alkenones under contrasting bottom water oxygen conditions: Implication for paleotemperature reconstruction, Geochim. Cosmochim. Ac., 63, 405-411, 1999.

Goñi, M. A., Yunker, M. B., Macdonald, R. W., and Eglinton, T. I.: The supply and preservation of ancient and modern components of organic carbon in the Canadian Beaufort Shelf of the Arctic 
Ocean, Mar. Chem., 93(1), 53-73, 2005.

Gooday, A. J. and Nott, J. A.: Intracellular barite cystals in two Xenophyophores, Aschemonella ramuliformis and Galatheammina sp. (protozoa: rhizopoda) with comments on the taxonomy of A. ramuliformis., J. Mar. Biol. Ass. UK, 62(3), 595-605, 1982.

Gough, M. A., Fauzi, R., Mantoura, C., and Preston, M.: Terrestrial plant biopolymers in marine sediments. Geochim. Cosmochim. Ac., 57, 945-964, 1993.

Guerra-Garcia, J. M. and García-Gómez, J. C.: Oxygen labels versus chemical pollutants: do they have similar influence on macrofaunal assemblages? A case study in a harbour with two opposing entrances, Environ. Pollut., 135, 281-291, 2005.

Gupta, N. S., Michels, R., Briggs, D. E. G., Collinson, M. E., Evershed, R. P., and Pancost, R. D.: Experimental evidence for the formation of geomacromolecules from plant leaf lipids, Org. Geochem., 38(1), 28-36, 2007.

Haider, K. K.: Problems related to the humification processes in soils of the temperate climate, in: Soil Biochemistry, edited by: Bollag, J.-M., Marcel Dekker, New York, 55-94, 1992.

Hanford, M. J. and Peeples, T. L.: Archaeal tetraether lipids, Appl. Biochem. Biotechnol., 97(1), 45-62, 2002.

Hartnett, H. E., Keil, R. G., Hedges, J. I., and Devol, A. H.: Influence of oxygen exposure time on organic carbon preservation in continental margin sediments, Nature, 391, 572-574, 1998.

Harvey, G. R., Boran D. A., Chesal, L. A., and Tokar, J. M.: The structure of marine fulvic and humic acid, Mar. Chem., 12, 119132, 1983.

Haug, G. H., Pedersen, T. F., Sigman, D. M., Calvert, S. E., and Nielsen, B.: Glacial/interglacial variations in production and nitrogen fixation in the Cariaco Basin during the last $580 \mathrm{kyr}$, Paleoceanogr., 13(5), 427-432, 1998.

Hedges, J. I., Cowie, G. L., Richey, J. E., Quay, P. D., Brenner, R., Strom, M., and Forsberg, B.: Origin and processing of organic matter in the Amazon River as indicated by carbohydrates and amino acids, Limnol. Oceanogr., 39(4), 743-761, 1994.

Hedges, J. I., Eglinton, G., Hatcher, P. G., Kirchman, D. L., Arnosti, C., Derenne, S., Evershed, R. P., Kögel-Knabner, I., de Leeuw, J. W., Littke, R., Michaelis, W., and Rullkötter, J.: The molecularly-uncharacterized component of nonliving organic matter in natural environments, Org. Geochem., 31, 945958, 2000.

Hedges, J. I., Hu, F. S., Devol, A. H., Hartnett, H. E., Tsamakis, E., and Keil, R. G.: Sedimentary organic matter preservation: a test for selective degradation under oxic conditions, Am. J. Sci., 229, 529-555, 1999.

Hedges, J. I. and Keil, R. G.: Sedimentary organic matter preservation: an assessment and speculative synthesis, Mar. Chem., 49, 81-115, 1995.

Hedges, J. I. and Keil, R. G.: Organic geochemical perspectives on estuarine processes: sorption reactions and consequences, Mar. Chem., 65, 55-65, 1999.

Hedges, J. I. and Mann, D. C.: The characterization of plant tissues by their lignin oxidation products, Geochim. Cosmochim. Ac., 43, 1803-1807, 1979.

Hedges, J. I. and Oades, J. M.: Comparative organic geochemistries of soils and marine sediments, Org. Geochem., 27, 319-361, 1997.

Hedges, J. I. and Prahl, F. G.: Early diagenesis: consequences for applications of molecular biomarkers, in: Organic Geochemistry,
Principles and Applications, edited by: Engel, M. H., Macko, S. A., and Jones, D. S., Plenum Press, New York, 237-253, 1993.

Heim, A. and Schmidt, M. W. I.: Lignin is preserved in the fine silt fraction of an arable Luvisol, Org. Geochem., 38(12), 20012011, 2007.

Hemsley, A. R., Barrie, P. J., and Chaloner, W. G.: Studies of fossil and modern spore and pollen wall biomacromolecules using ${ }^{13} \mathrm{C}$ solid state NMR, NERC Spec. Publ., 94(1), 15-19, 1994.

Herbert, T. D.: Alkenone paleotemperature determinations, in: The Oceans and marine geochemistry, edited by: Elderfield, H., Elsevier, Amsterdam, 391-432, 2003.

Herman, J. P., Middelburg, J. J., van de Koppel, J., and Heip, C. H. R.: Ecology of estuarine macrobenthos, Adv. Ecol. Res., 29, 195-240, 1999.

Hertkorn N., Benner, R., Frommberger, M., Schmitt-Kopplin, P., Witt, M., Kaiser, K., Kettrup, A., and Hedges, J. I.: Characterization of a major refractory component of marine dissolved organic matter, Geochim. Cosmochim. Ac., 70(12), 2990-3010, 2006.

Hilton, R. G., Galy, A., Hovius, N., Chen, M.-C., Horng, M.-J., and Chen, H.: Tropical-cyclone-driven erosion of the terrestrial biosphere from mountains, Nat. Geosci., 1, 759-762, 2008.

Higgs, N. C., Thomson, J., Wilson, T. R. S., and Croudace, I. W.: Modification and complete removal of eastern Mediterranean sapropels by postdepositional oxidation, Geology, 22, 423-426, 1994.

Hillenbrand, K.-D., Grobe, H., Diekmann, B., Kuhn, G., and Fütterer, D. K.: Distribution of clay minerals and proxies for productivity in surface sediments of the Bellingshausen and Amundsen seas (West Antarctica) - Relation to modern environmental conditions, Mar. Geol., 193(3-4), 253-271, 2003.

Hockaday, W. C., Grannas, A. M., Kim, S., and Hatcher, P. G.: Direct molecular evidence for the degradation and mobility of black carbon in soils from ultrahigh-resolution mass spectral analysis of dissolved organic matter from a fire-impacted forest soil, Org. Geochem., 37(4), 501-510, 2006.

Hoefs, M. J. L., Rijpstra, W. I. C., and Sinninghe Damsté, J. S.: The influence of oxic degradation on the sedimentary biomarker record I: Evidence from Madeira Abyssal Plain turbidites, Geochim. Cosmochim. Ac., 66, 2719-2735, 2002.

Hoefs, M. J. L., Versteegh, G. J. M., Rijpstra, W. I. C., de Leeuw, J. W., and Sinninghe Damsté, J. S.: Postdepositional oxic degradation of alkenones: implications for the measurement of palaeo sea surface temperatures, Paleoceanogr., 13(1), 42-49, 1998.

Holmes, E., Lavik, G., Fischer, G., and Wefer, G.: Nitrogen isotopes in sinking particles and surface sediments, in: The South Atlantic in the Late Quaternary, edited by: Wefer, G., Mulitza, S., and Rathmeyer, V., Springer, Berlin, 143-165, 2003.

Hopkins, J. A. and McCarthy, F. M. G.: Post-depositional palynomorph degradation in Quaternary shelf sediments: a laboratory experiment studying the effects of progressive oxidation, $\mathrm{Pa}$ lynol., 26, 167-184, 2002.

Hopmans, E. C., Weijers, J. W. H., Schefuss, E., Herfort, L., Sinninghe Damsté, J. S., and Schouten, S.: A novel proxy for terrestrial organic matter in sediments based on branched and isoprenoid tetraether lipids, Earth Planet. Sci. Lett., 224(1-2), 107116, 2004.

Hughey, C. A., Minardi, C. S., Galasso-Roth, S. A., Paspalof, G. B., Mapolelo, M. M., Rodgers, R. P., Marshall, A. G., and Ruder- 
man, D. L.: Naphthenic acids as indicators of crude oil biodegradation in soil, based on semi-quantitative electrospray ionization Fourier transform ion cyclotron resonance mass spectrometry, Rapid Commun. Mass Sp., 22, 3968-3976, 2008.

Huang, Y., Li, B., Bryant, C., Bol, R., and Eglinton, T. I.: Radiocarbon dating of aliphatic hydrocarbons: A new approach for dating passive-fraction carbon in soil horizons, Soil Sci. Soc. Am. J., 63, 1181-1187, 1999.

Huguet, C., de Lange, G. J., Gustafsson, O., Middelburg, J. J., Sinninghe Damsté, J. S., and Schouten, S.: Selective preservation of soil organic matter in oxidized marine sediments (Madeira Abyssal Plain), Geochim. Cosmochim. Ac., 72(24), 6061-6068, 2008.

Huguet, C., de Lange, G. J., Kim, J.-H., Sinninghe Damsté, J. S., and Schouten, S.: Selective preservation of soil-derivedglycerol diakyl glycerol tetraether lipids in oxidized marine sediments, in: $\mathrm{TEX}_{86}$ Paleothermometry: Proxy validation and application in marine sediments, edited by: Huguet, C., Utrecht University, Utrecht, 87-104, 2007.

Huguet, C., Kim, J.-H., de Lange, G. J., Sinninghe Damsté, J. S., and Schouten, S.: Effects of long-term oxic degradation on the $\mathrm{U}^{K}{ }_{37}, \mathrm{TEX}_{86}$ and BIT organic proxies, Org. Geochem., 40, 1188-1194, 2009.

Ishikawa A. and Taniguchi A.: Contribution of benthic cysts to the population dynamics of Scrippsiella spp. (Dinophyceae) in Onagawa Bay, northeast Japan, Mar. Ecol. Progr. Ser., 140, 169-178, 1996

Jenkyns, H. C., Gröcke, D. R., and Hesselbo, S. P.: Nitrogen isotope evidence for water mass denitrification during the Early Toarcian (Jurassic) oceanic anoxic event, Paleoceanogr., 16(6), 593-603, 2001.

Jorge, R. M. F. and Livingston, A. G.: A novel method for characterisation of microbial growth kinetics on volatile organic compounds, Appl. Microbiol., 52, 174-178, 1999.

Jung, M., Ilmberger, J., Mangini, A., and Emeis, K.-C.: Why some Mediterranean sapropels survived burn-down (and others did not), Mar. Geol., 141, 51-60, 1997.

Kasten, S., Haese, R. R., Zabel, M., Rühlemann, C., and Schulz, H. D.: Barium peaks at glacial terminations in sediments of the equatorial Atlantic Ocean - relicts of deglacial productivity pulses?, Chem. Geol., 175, 635-651, 2001.

Kasten, S., Zabel, M., Heuer, V., and Hensen, C.: Processes and signals of non-steady state diagenesis in deep-sea sediments, in: The South Atlantic in the Late Quaternary, edited by: Wefer, G., Mulitza, S., and Rathmeyer, V., Springer, Berlin, 431-459, 2003.

Keil, R. G., Tsamakis, E., Giddings, J. C., and Hedges, J. I.: Biochemical distributions (amino acids, neutral sugars, and lignin phenols) among size-classes of modern marine sediments from Washington coast, Geochim. Cosmochim. Ac., 62, 1347-1364, 1998.

Khanna, R., Witt, M., Anwer, K., Agarwal, S. P., and Koch, B. P.: Spectroscopic characterization of Fulvic Acids extracted from the rock exudate Shilajit, Org. Geochem. 39, 1719-1724, 2008.

Kiem, R. and Kögel-Knabner, I.: Contribution of lignin and polysaccharides to the refractory carbon pool in C-depleted arable soils, Soil Biol. Biochem., 35(1), 101-118, 2003.

Kim, J.-H., Huguet, C., Zonneveld, K. A. F., Versteegh, G. J. M., Sinninghe Damsté, J. S., and Schouten, S.: Stability of the $\mathrm{TEX}_{86}$ and $\mathrm{U}_{37}^{K^{\prime}}$ temperature proxies upon a one year field incu- bation experiment., Org. Geochem., 73, 2888-2898, 2009.

Kim, S. W., Kaplan, L. A., Benner, R., and Hatcher, P. G.: Hydrogen-deficient molecules in natural riverine water samples evidence for the existence of black carbon in DOM, Mar. Chem., 92(1-4), 225-234, 2004.

Knicker, H. and Hatcher, P. G.: Survival of protein in an organicrich sediment; possible protection by encapsulation in organic matter, Naturwissenschaften, 84(6), 231-234, 1997.

Knicker, H. and Hatcher, P. G.: Sequestration of organic nitrogen in the sapropel from Mangrove Lake, Bermuda, Org. Geochem., 32(5), 733-744, 2001.

Koch, B. P. and Dittmar, T.: From mass to structure: an aromaticity index for high-resolution mass data of natural organic matter, Rapid Commun. Mass. Sp., 20(5), 926-932, 2006.

Koch, B. P., Ludwichowski, K. U., Kattner, G., Dittmar, T., and Witt, M.: Advanced characterization of marine dissolved organic matter by combining reversed-phase liquid chromatography and FT-ICR-MS, Mar. Chem., 111, 233-241, 2008.

Koch, B. P., Witt M., Engbrodt R., Dittmar T., and Kattner, G.: Molecular formulae of marine and terrigenous dissolved organic matter detected by electrospray ionization fourier transform ion cyclotron resonance mass spectrometry, Geochim. Cosmochim. Ac., 69(13), 3299-3308, 2005.

Koch, B. P., Witt M., Kattner, G., and Dittmar, T.: Fundamentals of molecular formula assignment to ultrahigh resolution mass data of natural organic matter, Anal. Chem., 79, 1758-1763, 2007.

Kodrans-Nsiah, M., Zonneveld, K. A. F., and de Lange, G. J.: Species-selective aerobic degradation of dinoflagellate cysts - results of a natural exposure experiment, Rev. Palaeobot. Palyno., 152, 32-39, 2008.

Kokinos, J. P., Eglinton, T. I., Goñi, M. A., Boon, J. J., Martoglio, P. A., and Anderson, D. M.: Characterisation of a highly resistant biomacromolecular material in the cell wall of a marine dinoflagellate resting cyst, Org. Geochem., 28(5), 265-288, 1998.

Kramer, R. W., Kujawinski, E. B., and Hatcher, P. G.: Identification of black carbon derived structures in a volcanic ash soil humic acid by Fourier transform ion cyclotron resonance mass spectrometry, Env. Sci. Technol., 38, 3387-3395, 2004.

Kremp, A. and Heiskanen, A.-S.: Sexuality and cyst formation of the spring-bloom dinoflagellate Scrippsiella hangoei in the coastal northern Baltic Sea, Mar. Biol., 134, 771-777, 1999.

Kujawinski, E. B., Del Vecchio, R., Blough, N. V., Klein, G. C., and Marshall, A. G.: Probing molecular-level transformations of dissolved organic matter: insights on photochemical degradation and protozoan modification of DOM from electrospray ionization Fourier transform ion cyclotron resonance mass spectrometry., Mar. Chem., 92(1-4), 23-37, 2004.

Kujawinski, E. B., Freitas, M. A., Zang, X., Hatcher, P. G., GreenChurch, K. B., and Jones, R. B.: The application of electrospray ionization mass spectrometry (ESI MS) to the structural characterization of natural organic matter, Org. Geochem., 33(3), 171180, 2002.

Laws, E. A., Popp, B. N., Bidigare, R. R., Riebesell, U., Burkhardt, S., and Wakeham, S. G.: Controls on the molecular distribution and carbon isotopic composition of alkenones in certain haptophyte algae, Geochem. Geophys. Geosys., 2, 2000GC000057, doi:10.1029/2000GC000057, 2001.

Lehmann, M. F., Bernasconi, S. M., Barbieri, A., and McKenzie, J. A.: Preservation of organic matter and alteration of its car- 
bon and nitrogen isotope composition during simulated and in situ early sedimentary diagenesis, Geochim. Cosmochim. Ac., 66(20), 3573-3584, 2002.

Libes, S. M. and Deuser, W. G.: The isotope geochemistry of particulate nitrogen in the Peru upwelling area and the Gulf of Maine, Deep-Sea Res., 35(4), 517-533, 1988.

Marret, F.: Les effets de l'acétolyse sur les assemblages des kystes de dinoflagellés, Palynosci., 2, 267-272, 1993.

Marret, F. and Zonneveld, K. A. F.: Atlas of modern organic-walled dinoflagellate cyst distribution, Rev. Palaeobot. Palyno., 125(1), 1-200, 2003.

Marschner, B., Brodowski, S., Dreves, A., Gleixner, G., Gude, A., Grootes, P. M., Hamer, U., Heim, A., Jandl, G., Ji, R., Kaiser, K., Kalbitz, K., Kramer, C., Leinweber, P., Rethemeyer, J., Schaeffer, A., Schmidt, M. W. I., Schwark, L., and Wiesenberg, G. L. B.: How relevant is recalcitrance for the stabilization of organic matter in soils?, J. Plant. Nutr. Soil Sci., 171(1), 91-110, 2008.

Marshall, A. G., Hendrickson, C. L., and Jackson, G. S.: Fourier transform ion cyclotron resonance mass spectrometry: A primer, Mass Spectr. Rev., 17(1), 1-35, 1998.

Martrat, B., Grimalt, J. O., Shackleton, N. J., de Abreu, L., Hutterli, M. A., and Stocker, T. F.: Four climate cycles of recurring deep and surface water destabilisations on the Iberian Margin, Science, 317, 502-507, 2007.

Matthewson, A. P., Shimmield, G. B., Kroon, D., and Fallick, A. E.: A 300 kyr high-resolution aridity record of the North African continent, Paleoceanogr., 10(3), 667-692, 1995.

McKenna, A. M., Purcell, J. M., Rodgers, R. P., and Marshall, A. G.: Identification of vanadyl porphyrins in a heavy crude oil and raw asphaltene by atmospheric pressure photoionization fourier transform Ion cyclotron resonance (FT-ICR) mass spectrometry, Energy Fuel., 23(4), 2122-2128, 2009.

Meier, K. J. S., Zonneveld, K. A. F., Kasten, S., and Willems, H.: Different nutrient sources forcing increased productivity during eastern Mediterranean S1 sapropel formation as reflected by calcareous dinoflagellate cysts., Paleoceanogr., 19, PA1012, doi:10.1029/2003PA000895, 2004.

Meysman, F. J. R., Middelburg, J. J., and Heip, C. H. R.: Bioturbation: A fresh look at Darwin's last idea, Trends Ecol. Evol., 21(12), 688-695, 2006.

Middelburg, J. J. and Meysman, F. J. R.: Burial at sea, Science, 316, 1294-1295, 2007.

Möbius, J., Gaye, B., Lahajnar, N., Bahlmann, E., and Emeis, K.C.: Influences on sedimentary $\delta^{15} \mathrm{~N}$ in the Arabian Sea over the last $130 \mathrm{kyr}$, submitted to Geochim Gosmochim Ac., 2010.

Mollenhauer, G. and Eglinton, T. I.: Diagenetic and sedimentological controls on the composition of organic matter preserved in California Borderland Basin sediments, Limnol. Oceanogr., 52(2), 558-576, 2007.

Mollenhauer, G., Inthorn, M., Vogt, T., Zabel, M., Sinninghe Damsté, J. S., and Eglinton, T. I.: Aging of marine organic matter during cross-shelf lateral transport in the Benguela upwelling system revealed by compound-specific radiocarbon dating, Geochem. Geophys. Geosys., 8(9), Q09004, doi:10.1029/2007GC001603, 2007.

Monnin, C., Jeandel, C., Cattaldo, T., and Dehairs, F.: The marine barite saturation state of the world's oceans, Mar. Chem., 65(34), 253-261, 1999.

Montresor, M., Zingone, A., and Sarno, D.: Dinoflagellate cyst pro- duction at a coastal Mediterranean site, J. Plankton Res., 20(12), 2291-2312, 1998.

Moodley, L., Middelburg, J. J., Soetaert, K., Boschker, H. T. S., Herman, P. M. J., and Heip, C. H. R.: Similar rapid response to phytodetritus deposition in shallow and deep-sea sediments, J. Mar. Res., 63(2), 457-469, 2005.

Moore, W. S., Sarmiento, J. L., and Key, R. M.: Submarine groundwater discharge revealed by ${ }^{228} \mathrm{Ra}$ distribution in the upper Atlantic Ocean, Nat. Geosci., 1(5), 309-311, doi:10.1038/ngeo183, 2008.

Moreno, A., Nave, S., Kuhlmann, H., Canals, M., Targarona, J., Freudenthal, T., and Abrantes, F.: Productivity response in the North Canary Basin to climate changes during the last $250000 \mathrm{yr}$ : a multi-proxy approach, Earth Planet. Sci. Lett., 196(3-4), 147159, 2002.

Mudie, P. J. and McCarthy, F. M. G.: Marine palynology: potentials for onshore-offshore correlation of Pleistocene-Holocene records, Trans. Royal Soc. S. Afr., 61(2), 139-157, 2006.

Nürnberg, C. C., Bohrmann, G., Schlüter, M., and Frank, M.: Barium accumulation in the Atlantic sector of the Southern Ocean: Results from 190000-year records, Paleoceanogr., 12(4), 594603, 1997.

Ohkouchi, N., Eglinton, T. I., Keigwin, L. D., and Hayes, J. M.: Spatial and temporal offsets between proxy records in a sediment drift. Science, 298, 1224-1227, 2002.

Opsahl, S. and Brenner, R.: Distribution and cycling of terrigenous dissolved organic matter in the ocean, Nature, 386, 480-482, 1997.

Otto, A. and Simpson, M. J.: Evaluation of $\mathrm{CuO}$ oxidation parameters for determining the source and stage of lignin degradation in soil, Biogeochem., 80, 121-142, 2006.

Parkes, R. J., Cragg, B. A., Getliff, J. M., Harvey, S. M., Fry, S. E., Lewis, C. A., and Rowland, S. J.: A quantitative study of microbial decomposition of biopolymers in Recent sediments from the Peru Margin, Mar. Geol., 113, 55-66, 1993.

Passier, H. F., Bosch, H.-J., Nijenhuis, I. A., Lourens, L. J., Böttcher, M. E., Leenders, A., Sinninghe Damsté, J. S., de Lange, G. J., and de Leeuw, J. W.: Sulphidic Mediterranean surface waters during Pliocene sapropel formation, Nature, 397, 146-149, 1999.

Pearson, A. and Eglinton, T. I.: The origin of $n$-alkanes in Santa Monica Basin surface sediment: a model based on compoundspecific $\Delta^{14} \mathrm{C}$ and $\delta^{13} \mathrm{C}$ data, Org. Geochem., 31(11), 11031116, 2000.

Pfeifer, K., Kasten, S., Hensen, C., and Schulz, H. D.: Reconstruction of primary productivity from the barium contents in surface sediments of the South Atlantic Ocean, Mar. Geol., 177(1/2), 1324, 2001.

Pfiester, L. A. and Anderson, D. M.: Dinoflagellate life-cycles and their environmental control, in: The biology of dinoflagellates, edited by: Taylor, F. J. R., Blackwell Scientific Publishers, Oxford, 611-648, 1987.

Prahl, F. G.: Prospective use of molecular paleontology to test for iron limitation on marine primary productivity, Mar. Chem., 39(1-3), 167-185, 1992

Prahl, F. G., Collier, R. B., Dymond, J., Lyle, M., and Sparrow, M. A.: A biomarker perspective on prymnesiophyte productivity in the northeast Pacific Ocean, Deep-Sea Res. Pt. I, 40(10), 20612076, 1993. 
Prahl, F. G., Cowie, G. L., de Lange, G. J., and Sparrow, M. A.: Selective organic matter preservation in "burn-down" turbidites on the Madeira Abyssal Plain, Paleoceanogr., 18(2), 1052, doi:2002PA000853, 2003.

Prahl, F. G., de Lange, G. J., Lyle, M., and Sparrow, M. A.: Postdepositional stability of long-chain alkenones under contrasting redox conditions, Nature, 341, 434-437, 1989.

Prahl, F. G., Dymond, J., and Sparrow, M. A.: Annual biomarker record for export production in the central Arabian Sea, DeepSea Res. Pt. II, 47(7-8), 1581-1604, 2000.

Prahl, F. G., Mix, A. C., and Sparrow, M. A.: Alkenone paleothermometry: Biological lessons from marine sediment records off western South America, Geochim. Cosmochim. Ac., 70(1), 101117, 2006.

Prahl, F. G. and Muehlhausen, L. A.: Lipid biomarkers as geochemical tools for paleoceanographic study, in: Productivity of the Ocean: Present and Past, edited by: Berger, W. H., Smetacek, V. S., and Wefer, G., Wiley, Chichester, 271-289, 1989.

Qian, K., Mennito, A. S., Edwards, K. E., and Ferrughelli, D. T.: Observation of vanadyl porphyrins and sulfur-containing vanadyl porphyrins in a petroleum asphaltene by at- mospheric pressure photonionization Fourier transform ion cyclotron resonance mass spectrometry, Rapid Commun. Mass. Sp., 22, 2153-2160, 2008.

Reemtsma, T., These, A., Venkatachari, P., Xia, X. Y., Hopke ,P. K., Springer, A., and Linscheid, M.: Identification of fulvic acids and sulfated and nitrated analogues in atmospheric aerosol by electrospray ionization Fourier transform ion cyclotron resonance mass spectrometry, Anal. Chem., 78(24), 8299-8304, 2006.

Reitz, A., Pfeifer, K., de Lange, G. J., and Klump, J.: Biogenic barium and the detrital $\mathrm{Ba} / \mathrm{Al}$ ratio: a comparison of their direct and indirect determination, Mar. Geol., 204(3-4), 289-300, 2004.

Riedinger, N., Kasten, S., Gröger, J., Franke, C., and Pfeifer, K.: Active and buried authigenic barite fronts in sediments from the eastern Cape Basin. Earth Planet. Sci. Lett., 241 (3-4), 876-888, 2006.

Rethemeyer, J., Kramer, C., Gleixner, G., Wiesenberg, G. L. B., Schwark, L., Andersen, N., Nadeau, M. J., and Grootes, P. M.: Complexity of soil organic matter: AMS ${ }^{14} \mathrm{C}$ analysis of soil lipid fractions and individual compounds, Radiocarb., 46(1), 465-473, 2004.

Rodgers, R. P., Hendrickson, C. L., Emmett, M. R., Marshall, A. G., Greaney, M., and Qian, K. N.: Molecular characterization of petroporphyrins in crude oil by electrospray ionization Fourier transform ion cyclotron resonance mass spectrometry. Can. J. Chem., 79, 546-551, 2001.

Rontani, J.-F., Harji, R., Guasco, F., Prahl, F. G., Volkman, J. K., Bhosle, N. B., and Bonin, P.: Degradation of alkenones by aerobic heterotrophic bacteria: Selective or not?, Org. Geochem., 39, 34-51, 2008.

Rontani, J.-F. and Wakeham, S. G.: Alteration of alkenone unsaturation ratio with depth in the Black Sea: Potential roles of stereomutation and aerobic biodegradation, Org. Geochem., 39(9), 1259-1268, 2008.

Ross, O. N. and Sharples, J.: Swimming for survival: a role of phytoplankton motility in a stratified turbulent environment, J. Marine Syst., 70(3-4), 248-262, 2008.

Sachs, J. P. and Repeta, D. J.: Oligotrophy and nitrogen fixation dur- ing Eastern Mediterranean sapropel events, Science, 286, 24852488, 1999.

Schaub, T. M., Rodgers, R. P., Marshall, A. G., Qian, K., Green, L. A., and Olmstead, W. N.: Speciation of aromatic compounds in petroleum refinery streams by continuous flow field desorption ionization FT-ICR mass spectrometry, Energy Fuel., 19(4), 1566-1573, 2005.

Schefuss, E., Schouten, S., and Schneider, R. R.: Climatic controls on central African hydrology during the past 20000 years, Nature, 437, 1003-1006, 2005.

Schlesinger, W. H. and Melack, J. M.: Transport of organic carbon in the worlds rivers, Tellus, 33(2), 172-178, 1981.

Schmidt, F., Elvert, M., Koch, B. P., Witt, M., and Hinrichs, K.-U.: Molecular characterization of dissolved organic matter in pore water of continental shelf sediments, Geochim. Cosmochim. Ac., 73(11), 3337-3358, 2009.

Schneider, R. R., Price, B., Müller, P. J., Kroon, D., and Alexander, I.: Monsoon related variations in Zaire (Congo) sediment load and influence of fluvial silicate supply on marine productivity in the east equatorial Atlantic during the last 200000 years, Paleoceanogr., 12(3), 463-481, 1997.

Schouten, S., Hopmans, E. C., and Sinninghe Damsté, J. S.: The effect of maturity and depositional redox conditions on archaeal tetraether lipid palaeothermometry, Org. Geochem., 35, 567571, 2004.

Schulte, S., Rostek, F., Bard, E., Rullkötter, J., and Marchal, O.: Variations of oxygen-minimum and primary productivity recorded in sediments of the Arabian Sea, Earth Planet. Sci. Lett., 173(3), 205-221, 1999.

Schwarz, B., Mangini, A., and Segl, M.: Geochemistry of a piston core from Ontong Java plateau (western equatorial Pacific): Evidence for sediment redistribution and changes in paleoproductivity, Geol. Rundschau, 85(3), 536-545, 1996.

Simon, A., Poulicek, M., Velimirov, B., and MacKenzie, F. T.: Comparison of anaerobic and aerobic biodegradation of mineralized skeletal structures in marine and estuarine conditions, Biogeochem., 25, 167-195, 1994.

Sinninghe Damsté, J. S. and de Leeuw, J. W.: Analysis, structure and geochemical significance of organically-bound sulphur in the geosphere: State of the art and future research, Org. Geochem., 16, 1077-1101, 1990.

Sinninghe Damsté, J. S. and Schouten, S.: Is there evidence for a substantial contribution of prokaryotic biomass to organic carbon in Phanerozoic carbonaceous sediments? Org. Geochem., 26, 517-530, 1997.

Sinninghe Damsté, J. S., Kuypers, M. M. M., Schouten, S., Schulte, S., and Rullkötter, J.: The lycopane/ $\mathrm{C}_{31} n$-alkane ratio as a proxy to assess palaeoxicity during sediment deposition, Earth Planet. Sci. Lett., 209(1-2), 215-226, 2003.

Sinninghe Damsté, J. S., Rijpstra, W. I. C., and Reichart, G. J.: The influence of oxic degradation on the sedimentary biomarker record II, Evidence from Arabian Sea Sediments, Geochim. Cosmochim. Ac., 66, 2737-2754, 2002.

Sleighter, R. L. and Hatcher, P. G.: Molecular characterization of dissolved organic matter (DOM) along a river to ocean transect of the lower Chesapeake Bay by ultrahigh resolution electrospray ionization Fourier transform ion cyclotron resonance mass spectrometry, Mar. Chem., 110(3-4), 140-152, 2008.

Smittenberg, R. H., Eglinton, T. I., Schouten, S., and Sinninghe 
Damsté, J. S.: Ongoing buildup of refractory organic carbon in boreal soils during the Holocene, Science, 314(5803), 12831286, 2006.

Sollins, P., Homann, P., and Caldwell, B. A.: Stabilization and destabilization of soil organic matter: mechanisms and controls, Geoderma, 74(1-2), 65-105, 1996.

Stenson, A. C., Marshall, A. G., and Cooper, W. T.: Exact masses and chemical formulas of individual Suwannee River fulvic acids from ultrahigh resolution electrospray ionization Fourier transform ion cyclotron resonance mass spectra, Anal. Chem., 75(8), 1275-1284, 2003.

Struck U., Emeis, K.-C., Voss, M., Christiansen, C., and Kunzendorf, H.: Records of southern and central Baltic Sea eutrophication in $\delta^{13} \mathrm{C}$ and $\delta^{15} \mathrm{~N}$ of sedimentary organic matter, Mar. Geol., 164(3-4), 157-171, 2000.

Suess, E.: Particulate organic carbon flux in the oceans - surface productivity and oxygen utilization, Nature, 288, 260-263, 1980.

Sun M.-Y. and Wakeham, S. G.: Molecular evidence for degradation and preservation of organic matter in the anoxic Black Sea Basin, Geochim. Cosmochim. Ac., 58, 3395-3406, 1994.

Susek E., Zonneveld, K. A. F., Fischer, G., Versteegh, G. J. M., and Willems, H.: Organic-walled dinoflagellate cyst production related to variations in upwelling intensity and lithogenic influx in the Cape Blanc region (off NW Africa), Phycol. Res., 53(2), 97-112, 2005.

Teece, M. A., Getliff, J. M., Leftley, J. W., Parkes, R. J., and Maxwell, J. R.: Microbial degradation of the marine prymnesiophyte Emiliania huxleyi under oxic and anoxic conditions as a model for early diagenesis: long chain alkadienes, alkenones and alkyl alkenoates, Org. Geochem., 29, 863-880, 1998.

Tendal, O. S.: A monograph of the Xenophyophoria (Rhizopoda, Protozoa), Galathea Report, 12, 1-103, 1972.

Thomson, J., Higgs, N. C., Wilson, T. R. S., Croudace, I. W., de Lange, G. J., and van Santvoort, P. J. M.: Redistribution and geochemical behaviour of redox-sensitive elements around S1, the most recent eastern Mediterranean sapropel, Geochim. Cosmochim. Ac., 59(17), 3487-3501, 1995.

Thomson, J., Mercone, D., de Lange, G. J., and van Santvoort, P. J. M.: Review of recent advances in the interpretation of eastern Mediterranean sapropel S1 from geological evidence, Mar. Geol., 153, 77-89, 1999.

Torres, M. E., Brumsack, H. J., Bohrmann, G., and Emeis, K. C.: Barite fronts in continental margin sediments: a new look at barium remobilization in the zone of sulfate reduction and formation of heavy barites in diagenetic fronts, Chem. Geol., 127(1-3), 125-139, 1996.

Trumbore, S. E. and Zheng, S. H.: Comparison of fractionation methods for soil organic matter 14C analysis, Radiocarb., 38(2), 219-229, 1996.

van Dongen, B. E.: Natural sulfurization of carbohydrates in marine sediments: consequences for the chemical and carbon isotopic composition of sedimentary organic matter, Geol. Ultratrajectina, 224, 1-149, 2003.

van Nugteren, P., Herman, P. M. J., Moodley, L., Middelburg, J. J., Vos, M., and Heip, C. H. R.: Spatial distribution of detrital resources determines the outcome of competition between bacteria and a facultative detrivorous worm, Limnol. Oceanogr., 54(4), 1413-1419, 2009.

Van Os, B. H. H., Lourens, L. J., Hilgen, F. J., de Lange, G. J., and Beaufort L.: The formation of Pliocene sapropels and carbonate cycles in the Mediterranean - diagenesis, production and productivity, Paleoceanogr., 9(4), 601-617, 1994.

van Santvoort, P. J. M., de Lange, G. J., Langereis, C. G., Dekkers, M. J., and Paterne, M.: Geochemical and paleomagnetic evidence for the occurrence of "missing" sapropels in eastern Mediterranean sediments, Paleoceanogr., 12(6), 773-786, 1997.

van Santvoort, P. J. M., de Lange, G. J., Thomson, J., Cussen, H., Wilson, T. R. S., Krom, M. D., and Ströhle, K.: Active postdepositional oxidation of the most recent sapropel (S1) in sediments of the eastern Mediterranean Sea, Geochim. Cosmochim. Ac., 60, 4007-4024, 1996.

Vandewiele, S., Cowie, G., Soetaert, K., and Middelburg, J. J.: Amino acid biogeochemistry and organic matter degradation state across the Pakistan margin oxygen minimum zone, DeepSea Res. Pt. II, 56(6-7), 376-392, 2009.

Versteegh, G. J. M. and Blokker, P.: Resistant macromolecules of extant and fossil microalgae, Phycol. Res., 52(4), 325-339, 2004.

Versteegh, G. J. M., Blokker, P., Marshall, C. R., and Pross, J.: Macromolecular composition of the dinoflagellate cyst Thalassiphora pelagica (Oligocene, SW Germany), Org. Geochem., 38, 1643-1656, 2007.

Versteegh, G. J. M., Blokker, P., Wood, G., Collinson, M. E., Sinninghe Damsté, J. S., and de Leeuw, J. W.: Oxidative polymerization of unsaturated fatty acids as a preservation pathway for microalgal organic matter, Org. Geochem., 35, 1129-1139, 2004.

Versteegh, G. J. M., Riegman, R., de Leeuw, J. W., and Jansen, J. H. F.: $\mathrm{U}_{37}^{K^{\prime}}$ values for Isochrysis galbana as a function of culture temperature, light intensity and nutrient concentrations, Org. Geochem., 32, 785-794, 2001.

Versteegh, G. J. M. and Zonneveld, K. A. F.: Use of selective degradation to separate preservation from productivity, Geology, 30(7), 615-618, 2002.

Villanueva, J., Grimalt, J. O., Labeyrie, L. D., Cortijo, E., Vidal, L., and Turon, J.-L.: Precessional forcing of productivity in the North Atlantic Ocean, Paleoceanogr., 13(6), 561-571, 1998.

von Lützow, M., Kögel-Knabner, I., Ekschmitt, K., Heinz, F., Guggenberger, G., Matzner, E., and Marschner, B.: SOM fractionation methods: Relevance to functional pools and to stabilization mechanisms, Soil Biol. Biochem., 39(9), 2183-2207, 2007.

Wada, E., Goldberg, E. D., Horibe, Y., and Saruhashi, K.: Nitrogen isotope fractionation and its significance in biogeochemical processes occurring in marine environments, in: Isotope Marine Chemistry, edited by: Goldberg, E. D., Horibe, Y., and Saruhashi, K., Uchida Rokakuho, Tokyo, 375-398, 1980.

Wakeham, S. G. and Canuel, E. A.: Degradation and preservation of organic matter in marine sediments, in: Handbook of Environmental Chemistry, Hutzinger, O., Springer, Berlin, 295-321, 2006.

Wakeham, S. G., Lee, C., Hedges, J. I., Hernes, P. J., and Peterson, M. L.: Molecular indicators of diagenetic status in marine organic matter, Geochim. Cosmochim. Ac., 61, 5363-5369, 1997.

Wakeham, S. G., Peterson, M. L., Hedges, J. I., and Lee, C.: Lipid biomarker fluxes in the Arabian Sea, with a comparison to the equatorial Pacific Ocean, Deep-Sea Res. Pt. II, 49(12), 22652301, 2002.

Walinsky, S. E., Prahl, F. G., Mix, A. C., Finney, B. P., Jaeger, J. M., and Rosen, G. P.: Distribution and composition of organic 
matter in surface sediments of coastal Southeast Alaska. Cont. Shelf Res., 29, 1565-1579, 2009.

Weijers, J. W. H., Schouten, S., Spaargaren, O. C., and Sinninghe Damsté, J. S.: Occurrence and distribution of tetraether membrane in soils: Implications for the use of the BIT index and the TEX $_{86}$ SST proxy, Org. Geochem., 37, 1680-1693, 2006.

Weldeab, S., Emeis, K.-C., Hemleben, C., Schmiedl, G., and Schulz, H.: Spatial productivity during formation of Sapropels S5 and S6 in the Mediterranean Sea: evidence from Ba contents, Palaeogeogr. Palaeoclimatol. Palaeoecol., 191, 169-190, 2003a.

Weldeab, S., Siebel, W., Wehausen, R., Emeis, K.-C., Schmiedl, G., and Hemleben, C.: Late Pleistocene sedimentation in the Western Mediterranean Sea: implications for productivity changes and climatic conditions in the catchment areas, Palaeogeogr. Palaeoclimatol. Palaeoecol., 190, 121-137, 2003b.

Wiesenberg, G. L. B., Schwartzbauer, J., Schmidt, M. W. I., and Schwark, L.: Plant and soil lipid modification under elevated atmospheric $\mathrm{CO} 2$ conditions: II. Stable carbon isotopic values $\left(\delta^{13} \mathrm{C}\right)$ and turnover, Org. Geochem., 39(1), 103-117, 2008.

Williams, P. M. and Druffel, E. R. M.: Radiocarbon in dissolved organic-matter in the Pacific Ocean, Nature, 330, 246-248, 1987.

Witt, M., Fuchser, J., and Koch, B. P.: Fragmentation studies of fulvic acids using collision induced dissociation fourier transform ion cyclotron resonance mass spectrometry, Anal. Chem., 81(7), 2688-2694, 2009.
Zonneveld, K. A. F., Bockelmann, F.-D., and Holzwarth, U.: Selective preservation of organic walled dinoflagellate cysts as a tool to quantify past net primary production and bottom water oxygen concentrations, Mar. Geol., 237(3-4), 109-126, doi:10.1016/j.margo.2006.10.023, 2007.

Zonneveld, K. A. F., Susek, E., and Fischer, G.: Seasonal variability of the organic-walled dinoflagellate cyst production in the coastal upwelling region off Cape Blanc (Mauritania): a five-year survey, J. Phycol., 46(1), 202-215, 2010.

Zonneveld, K. A. F., Chen L., Möbius, J., and Mahmoud, M. S.: Environmental significance of dinoflagellate cysts from the proximal part of the Po-river discharge plume (off southern Italy, Eastern Mediterranean)., J. Sea Res., 62, 189-213, 2009.

Zonneveld, K. A. F., Versteegh, G. J. M., and de Lange, G. J.: Preservation of organic walled dinoflagellate cysts in different oxygen regimes: a 10000 years natural experiment, Mar. Micropaleontol., 29, 393-405, 1997.

Zonneveld, K. A. F., Versteegh, G. J. M., and Kodrans-Nsiah, M.: Preservation of Late Cenozoic organic-walled dinoflagellate cysts; a review, Mar. Micropaleontol., 86, 179-197, 2008. 